\title{
Structural styles and decoupling in stratigraphic sequences with double décollements during thin-skinned contractional tectonics: Insights from numerical modelling
} DOI:

10.1016/j.jsg.2019.103862

\section{Document Version \\ Accepted author manuscript}

Link to publication record in Manchester Research Explorer

Citation for published version (APA):

Meng, Q., \& Hodgetts, D. (2019). Structural styles and decoupling in stratigraphic sequences with double décollements during thin-skinned contractional tectonics: Insights from numerical modelling. Journal of Structural Geology, 127, 103862. https://doi.org/10.1016/j.jsg.2019.103862

\section{Published in:}

Journal of Structural Geology

\section{Citing this paper}

Please note that where the full-text provided on Manchester Research Explorer is the Author Accepted Manuscript or Proof version this may differ from the final Published version. If citing, it is advised that you check and use the publisher's definitive version.

\section{General rights}

Copyright and moral rights for the publications made accessible in the Research Explorer are retained by the authors and/or other copyright owners and it is a condition of accessing publications that users recognise and abide by the legal requirements associated with these rights.

\section{Takedown policy}

If you believe that this document breaches copyright please refer to the University of Manchester's Takedown Procedures [http://man.ac.uk/04Y6Bo] or contact uml.scholarlycommunications@manchester.ac.uk providing relevant details, so we can investigate your claim.

\section{OPEN ACCESS}




\section{Structural styles and decoupling in stratigraphic sequences with double}

2 décollements during thin-skinned contractional tectonics: insights from

3 numerical modelling

$4 \quad$ Qingfeng Meng*1, David Hodgetts

5 School of Earth and Environmental Sciences, University of Manchester, M13 9PL, UK

\section{Abstract}

7 Six series of particle-based numerical experiments were performed to simulate thin-skinned

8 contractional tectonics in stratigraphic sequences with double décollements during horizontal

9 shortening. The models were assigned with varying rock competence, depth and thickness of the

10 upper décollement, which resulted in significantly different styles of deformation and decoupling

11 characteristics above and below the upper décollement. The models composed of the least

12 competent material produced distributed sinusoidal detachment folds, with many shallow

13 structures profoundly decoupled from the deep-seated folds. The models composed of a more

14 competent material are dominated by faulted box folds, with minor disharmonic folds developed

15 in their limbs. In contrast, the results of models composed of the most competent material are

16 characterised by localised piggyback thrusts, fault-bend folds and pop-up structures with tensile

17 fractures developed in fold hinges. Depth of the upper décollements also plays an important role

18 in controlling structural decoupling, i.e. the shallower the upper décollements, the higher the

19 degree of decoupling becomes. Thicker upper décollements can provide sufficient mobile

20 materials to fill fold cores, and contribute to the formation of secondary disharmonic folds, helping

21 enhance structural decoupling. Our modelling results are comparable to the structural features

\footnotetext{
1 *Corresponding author. E-mail address: meng.qingfeng@ hotmail.com
} 
22 exhibited in the Dezful Embayment of the Zagros Fold-and-Thrust Belt with the Miocene

23 Gachsaran Formation acting as the shallow upper décollement, and the Fars with the Triassic

24 Dashtak Formation as its intermediate décollement. This study demonstrates that rock competence,

25 depth and thickness of the upper décollements can jointly affect the structural styles and 26 decoupling. Our modelling results are instructive for structural interpretation of deep zones in fold-

27 and-thrust belts that exhibit distinct structural decoupling features.

\section{Key words}

29 structural decoupling; fold-and-thrust belt; décollement; discrete element; Zagros

\section{Introduction}

32 Thin-skinned deformation styles are typical of many fold-and-thrust (FAT) belts in the foreland of 33 a collisional zone (Chapple, 1978). In such systems, a basal weak layer (e.g. shale and evaporite)

34 serves as the main décollement that allows the deformed overburden to be detached during 35 shortening (Davis and Engelder, 1985). Two or multiple décollements have been reported in many 36 FAT belts worldwide, such as the Apennines in Italy (Massoli et al., 2006; Tavani and Cifelli, 37 2010), the Jura in Switzerland (Sommaruga, 1999; Schori et al., 2015), the Salt Range in Parkistan 38 (Jaumé and Lillie, 1988; Gee and Gee, 1989), the Subandean in Bolivia (Leturmy et al., 2000; 39 Driehaus et al., 2014), the Kuqa in China (Wang et al., 2011; Izquierdo-Llavall et al., 2018), and 40 the Zagros in Iran (Sepehr et al., 2006), among others. The occurrence of multidécollements can 41 shape the variable geometry of FAT belts and affect the forward propagation of deformation 42 (Sherkati et al., 2006; Ghanadian et al., 2017a). In particular, deformation above and below the 43 upper décollement are commonly decoupled, which significantly increases structural complexity 
44 of the systems and makes it difficult to unravel deep structures beneath the upper décollement 45 (Derikvand et al., 2018).

47 A thorough understanding of the styles of deformation and decoupling of FAT belts is crucial partially due to their economic importance, given the fact that FAT belts constitute the most

49 prolific hydrocarbon provinces globally (Cooper, 2007). More fundamentally, this can yield insights into the competing mechanisms for accommodation of thin-skinned shortening (Erickson,

51 1996), i.e. thrusting, folding and diapirism (Bonini, 2003; Najafi et al., 2018) and salt deformation

52 in rifted continential margins (Alves et al., 2017), and geologic conditions required for 53 coupling/decoupling of deformation. Extensive field and seismic based observational studies 54 (Sherkati et al., 2005; Casciello et al., 2009; Farzipour- Saein et al., 2009; Fard et al., 2011; Vergés et al., 2011; Motamedi et al., 2012; Ghanadian et al., 2017b; Jahani et al., 2017; Najafi et al., 2018;

56 Derikvand et al., 2019), analogue modelling (Bahroudi and Koyi, 2003; Sherkati et al., 2006;

57 Konstantinovskaya and Malavieille, 2011; Driehaus et al., 2014; Ghazian and Buiter, 2014;

58 Santolaria et al., 2015; Farzipour-Saein and Koyi, 2016; Ghanadian et al., 2017c; Borderie et al., 59 2018) and numerical modelling studies (Ruh et al., 2012, 2017; Feng et al., 2015) have been 60 conducted to address questions in FAT belts with double or multiple décollements. It has been 61 realized that rock mechanical properties (Dean et al., 2013; Morgan, 2015; Meng and Hodgetts, 62 2019), décollements depth (Sepehr et al., 2006; Sherkati et al., 2006; Motamedi et al., 2012) and 63 thickness (Stewart, 1996, 1999; Costa and Vendeville, 2002; Meng and Hodgetts, 2019) can 64 determine the structural styles and decoupling in the shallow and deep segments of FAT belts. 65 Nevertheless, a more comprehensive study of the combined impact of these parameters is needed. 66 
67 This study reports a numerical modelling study of thin-skinned tectonics in FAT belts, with 68 varying rock mechanical competence, thickness and depth of the upper décollement. The aims are 69 1) to produce realistic geologic structures comparable to natural examples; 2) to examine the 70 controls on structural styles and the competing mechanisms for shortening accommodation in FAT

71 belts with two dominant décollement levels; to 3) to investigate the role of the upper décollement 72 in structural decoupling above and below the upper décollement. Notably, some other factors, such 73 as existence of pre-existing structures (Callot et al., 2012), mechanical stratigraphy (Sepehr et al., 74 2006; Farzipour-Saein et al., 2009), basal décollement thickness ((Bahroudi and Koyi, 2003; Meng 75 and Hodgetts, 2019), synkinematic sedimentation (Driehaus et al., 2014) and crustal shortening 76 rate (McQuarrie, 2004), can also play an important role in structural development of a thin-skinned 77 FAT belts with two or multiple décollements. However, this is beyond the scope of the current 78 study. The modelling results presented here exhibit first-order structural similarities to the Fars 79 and Dezful Embayment of the Zagros FAT Belt, and are believed to be of important implications 80 for structural interpretation of deep zones in FAT belts with double or multiple décollements and 81 prominent structural decoupling characteristics.

\section{Methodology}

\section{$84 \quad 2.1$. Fundamentals of the discrete element method}

85 The discrete element method is a particle-scale numerical method for modelling the bulk mechanical behavior of a system comprised of an assembly of discrete particles (Cundall and

87 Strack, 1979). A single particle is treated as a rigid circular body that occupies a finite amount of space. A discrete element model is composed of distinct particles that displace independently from others, and elastically interact with their neighbouring particles at particle contacts using a soft 
90 touch approach (i.e. the particles were considered rigid with a "soft" contact that allows particle

91 overlapping). The particle contact is defined as a linear spring in compression (Fig. 1) that resists

92 particle overlap, with the magnitude of particle overlap determined by the contact force via the

93 force-displacement law. The particles are allowed to be bonded together by applying interparticle

94 bonding at their contacts in order to resist both shear and extensional displacement. If either the

95 normal or shear bond strength is exceeded, the bond breaks, resulting in the formation of

96 microfractures. Coalescence of adjacent microfractures leads to fracture propagation and

97 formation of macro scale fractures. Slip between particles that is resisted by a frictional strength

98 can occur between particles with unbonded contacts. The mechanical behaviour of a discrete

99 element system is characterised by movement of each particle and inter-particle forces acting at

100 particle contacts, which is governed by Newton's laws of motion. At all times, the forces acting

101 on any particle are exclusively determined by its interaction with the particles with which it is in

102 contact. The interaction of particles is regarded as a non-linear dynamic process with the states of 103 equilibrium developing whenever the internal forces balance.

105 The discrete element method was initially developed to investigate the mechanical behavior of a 106 granular media, which has been applied to soil and rock mechanics studies (Cundall and Strack, 107 1979). In recent year, the discrete element method has been effectively used for addressing 108 questions in structural geology and tectonics. In particular, this method has been successfully 109 adopted to simulate detachment folds (Hardy and Finch, 2005; Vidal-Royo et al., 2011), fold110 related folds (Finch et al., 2003, 2004; Cardozo et al., 2005; Hardy and Finch, 2006, 2007; Benesh 111 et al., 2007; Hughes et al., 2014; Hardy, 2018) and fold-and-thrust belts (Burbidge and Braun, 
112 2002; Naylor et al., 2005; Dean et al., 2013; Morgan, 2015; Meng and Hodgetts, 2019), and is

113 therefore considered to be an ideal method for the current study.

\section{2.2. Model initial and boundary conditions}

116 The Particle Flow Code (Cundall and Strack, 1999) software was employed to construct six series 117 of two-dimensional discrete element models. Each model consists of a $20 \mathrm{~km}$ long, rectangular118 shaped box filled with densely-packed circular particles (Fig. 1). All the models have a $150 \mathrm{~m}$ 119 thick basal décollement that comprises 12653 particles. Models 1-9 of series 1 have a thinner upper 120 décollement with a thickness of $75 \mathrm{~m}$. Models 10-18 of series 4-6 have an equally thick upper 121 décollement to the basal décollement. The upper décollement in the models of series 1 and 4 have 122 the shallowest burial depth with only two rock layers above them, followed by models of series 2 123 and 5 which have 3 layers above them. Models of series 3 and 6 have 6 layers above the upper 124 décollement. The stratigraphic units also contain eight homogeneous layers that represent the bulk 125 rock. Each layer is $150 \mathrm{~m}$ thick and contains 1580 particles. The colours assigned for the layers do 126 not indicate mechanical contrasts, but are simply used for bedding correlations.

128 The particle radii range from 5.0 to $10.0 \mathrm{~m}$ for the décollement layer (e.g. shale or salt), and 10.0 129 to $32.0 \mathrm{~m}$ for the bulk rock, both following a Gaussian distribution of particle size so as to inhibit 130 hexagonal close packing of particles. Particle density is $2100 \mathrm{~kg} / \mathrm{m}^{3}$ for the décollement and 2600

$131 \mathrm{~kg} / \mathrm{m}^{3}$ for the bulk rock. Interparticle friction was prescribed to be 0.4 throughout the bonded 132 domain, and 0 within the décollements to ensure its low strength (Morgan, 2015). 
134 The particle stiffness (normal and shear) of the bulk rock was set to be $1 \times 10^{7} \mathrm{~N} / \mathrm{m}$, which has 135 been effectively used to represent sedimentary rocks at shallow depths (Liu and Konietzky, 2018). 136 A bonding cohesion of 1.0,2.5 and 5.0 MPa was prescribed to the three types of materials 1,2 and

137 3. We then performed numerical rock mechanics tests following the procedure described by 138 Cundall and Strack (1999), in order to derive the corresponding macroscopic mechanical 139 parameters. In such tests, synthetic rock samples were created and loaded in a strain-controlled 140 fashion by displacing the boundary walls at a sufficiently slow rate, so as to attain a quasistatic 141 solution. The stresses and strains experienced by the rock sample were determined in a macro142 fashion by summing the forces acting upon walls and tracking the relative distance between the 143 walls. The test results reveal that the Young's Modulus for the three types of materials is 21.14 $144 \mathrm{MPa}$, whilst the unconfined compressive strength (UCS) for materials 1, 2 and 3 is $1.87,3.51$ and $145 \quad 3.54 \mathrm{MPa}$, respectively.

147 The particles were packed by allowing randomly-generated particles to settle to the bottom of 148 model under gravitational force. The system was considered to have reached static equilibrium 149 when the mean unbalanced forces have been reduced to a negligible value. The particle assembly 150 was then trimmed to the desired thickness, which gave rise to a small amount of vertical elastic 151 rebound and surface uplift. This was followed by repeated trimming processes that allowed the 152 system to be settled (Benesh et al., 2007).

154 The three elastic walls served as the confined boundaries for the particle assembly, and the upper 155 surface was free. The left wall advanced at a controlled, uniform rate to the right, i.e. towards the 
156 foreland direction, to yield horizontal shortening and tectonic deformation in the system (Fig. 1).

157 The models were gravitationally loaded by $1 \mathrm{~g}$.

159 We present six snapshots of each model during the sequential shortening and deformation process, 160 to analyse their structural development and compare the results of models $a, b$ and $c$ in the various 161 series that involve the weakest to strongest layers. In particular, we focused on the features of 162 structural decoupling and their variances exhibited in different models, to gain insights into the 163 dominant controls.

\section{Results}

$166 \quad$ 3.1. Series 1

\section{3.1.1. Model 1}

168 The modelling result of model 1 (see model constraints in Fig. 1 and Table 1) is characterised by 169 successive formation of multiple short-wavelength detachment folds that spread across the entire 170 section (Fig. 2a). The first-order folds individually consist of multiple second-order parasitic folds 171 that exhibit a much smaller fold wavelength and amplitude. The early-formed, symmetrical fold

172 F1 is composed of two minor disharmonic folds in the orange layer that grew by consistent fold 173 tightening with an increasing fold amplitude. F2 started to appear as a symmetric detachment fold 174 from T4, and continued to grow till T7. At T6, a forethrust began to be initiated when the fold was 175 right-verging, which was accompanied with décollement material rising from the basal 176 décollement. During T6 to T7, F2 evolved into a fault-propagation fold as a result of propagation 177 of the forethrust and a clock-wise rotation of its forelimb. Notably, the stratigraphic units above 178 and below the upper décollement exhibit a profound structural decoupling, which is represented 
179 by the fact that the deep-seated folds barely propagated to the surface, and the superficial layer 180 remained largely planar.

182 The model accommodated crustal shortening mainly by thickening across the entire system (Table

183 1). The variances in crustal thickening result in a rather smooth downslope with a slope angle of $1849.3^{\circ}$. The rising material from the basal décollement in model 1 are much shorter than those in 185 other models in this series.

\subsubsection{Model 2}

188 The deformation structures formed in model 2 are characterised by three similar-sized box folds 189 originated from the basal décollement (Fig. 2b). Fold F1 was initiated as a symmetrical box fold 190 with oppositely dipping axial surfaces and a sub-vertical diapir as its core. This was followed by 191 the development of a minor fold F2 on the left of F1. Both folds continued to grow until T4 when 192 F3 and F4 were initiated. During this period, the fold axes of F1 exhibited a slight clockwise 193 rotation. F3 and F4 exhibited a right vengeance during T4 to T6, which resulted in the formation 194 of disharmonic folds in the orange layer. F5 began to develop at T6, and evolved into a regularly195 shaped box fold.

197 Structural decoupling commonly occurred, which is represented by the development of minor 198 disharmonic folds localised in the layers above the upper décollement. Such folds were developed 199 in the limbs of the deeply rooted folds as secondary structures, and significantly affect the surface 200 topography. The folds all amplified towards the surface, resulting in folding of the superficial 201 layers above the upper décollement. The rising material from the décollement exhibit a more 
202 distinct geometry and a larger size than those in model 1 (Table 1). The accommodation of 203 shortening was mainly achieved by fold amplification.

\subsubsection{Model 3}

206 The modelling result of model 3 is characterised by the formation of piggy-back thrusts (Fig. 2c). 207 Initially, F1 with disharmonic inner units were formed, which later developed into a fault208 propagation fold with a forethrust, and subsequently into a fault-bend fold. The hangingwall layers 209 were bent upward and transported passively along the ramp. F2 was formed at T4 and evolved into 210 a fault-propagation fold with a forethrust at T5. As shortening continued, the hangingwall layers 211 of the fault within F1 reached the backlimb of F2, resulting in a piggy-back arrangement of layers. 212 At T6, the dispir inside F2 rose up to the level of the upper décollement, and subsequently 213 propagated along the upper décollement. The persistent accumulation of displacement of the fault 214 within F2 led to the formation of a minor pop-up structure located in the front of F2.

Structural decoupling occurred at T4, when a fault-propagation fold with a backthrust was formed 217 in the superficial layers on the forelimb of F2. The pop-up structure formed in front of F2 caused 218 significant uplift and buckling of the superficial rocks. The result of model 3 exhibits a strong 219 strain localisation rather than distributed strain as shown in models 1 and 2. Horizontal shortening 220 was mainly accommodated by the development of forethrusts, whilst the foreland remained largely 221 undeformed (Table 1). This resulted in a dramatic uplift of the layers on the left of the model, and 222 a relatively steep downslope of $39.1^{\circ}$.

\subsection{Series 2}




\subsubsection{Model 4}

The deformation of model 4 is characterised by successive formation of multiple sinusoidal minor detachment folds towards the foreland direction (Fig. 3a). Some folds contain second-order parasitic folds developed in their limbs. The folds developed above and below the upper décollement are approximately similar, although significant differences appear locally.

The entire system has contributed to the accommodation of crustal shortening through thickening (Table 1). This produced a gentle downslope with a slope angle of $8.3^{\circ}$. Compared to the other two models in this series, model 4 exhibits the strongest structural decoupling, particularly between the surficial layer and the deep layers.

\subsubsection{Model 5}

Model 5 successively produced three dominant asymmetric folds towards the foreland direction (Fig. 3b), following the process of serial folding (Blay et al., 1977). F1 was initiated at T2 as a detachment fold and subsequently evolved into a fault-propagation fold with a backthrust. The fold continued to grow from T2 to T5, which was accompanied with the growth of its dispir. A forethrust was generated in its forelimb at T4. At T5, a symmetric box fold F2 was initiated, which later became asymmetric by clockwise rotation of its forelimb. F3 was formed at T6, and evolved into fault-propagation fold with a backthrust. In this model, horizontal shortening was predominantly accommodated by folding. The undeformed foreland is $2.33 \mathrm{~km}$ long (Table 1).

\subsubsection{Model 6}


247 Model 6 produced two imbricate thrusts with the hangingwall layers of the early-formed thrust 248 arranged as the first horse (Fig. 3c). F1 was initially formed at T3 as a fault-propagation fold with 249 a forethrust, which later evolved into a fault-bend fold. The material from the basal décollement 250 was stimulated to move to the surface at T4, and was subsequently transported in the sub-horizontal 251 direction. F2 was formed on the right of the model as a fault-bend fold with a backthrust at T6.

252 The system accommodated shortening mainly though fold amplification at the initial stage and 253 accumulation of fault displacement at the later stage. Deformation is largely localised to the 254 piggyback thrusts, and the unreformed foreland area reaches $5.26 \mathrm{~km}$ long (Table 1).

\subsection{Series 3}

\section{$257 \quad$ 3.3.1. Model 7}

258 The modelling result of model 7 is characterised by successive formation of multiple short259 wavelength sinusoidal folds below the upper décollement and larger folds above the upper 260 décollement (Fig. 4a). The fold traces below and above the upper décollement are generally 261 parallel, although disharmonic folds below the upper décollement occur locally. The system 262 accommodated crustal shortening mainly by thickening (Table 1). The variances in crustal 263 thickening result in a downslope with a slope angle of $9.1^{\circ}$.

\subsubsection{Model 8}

266 Model 8 produced two dominant box folds during the shortening process (Fig. 4b). F1 was initially 267 formed at T2 as a symmetric box fold, which became asymmetric at T3 by anticlockwise rotation 268 of the fold axial plane. Interestingly, the fold axial plane of F1 rotated clockwise with its core 269 dipping towards the hinterland direction. This was accompanied with the formation of F2, a minor 
270 fold developed in the forelimb of F1. The rising décollement material within F2 was dipping 271 oppositely to that within F1, i.e. towards the foreland. Meanwhile, F3 was formed in the foreland

272 as a fault-propagation fold with a backthrust. Later on, F1 and F2 had a vergence towards the fold 273 hinge. F4, a minor fault-propagation fold with a forethrust, was formed in the forelimb of F3.

274 Finally, F2 became merged with F1, and F4 merged with F3. Notably, F3 experienced a clockwise 275 rotation of its axial plane. The system accommodated shortening mainly by growth of the two 276 dominant folds. The undeformed foreland is $4.46 \mathrm{~km}$ long (Table 1).

277

$278 \quad$ 3.3.3. Model 9

279 The modelling result of model 9 is characterised by the formation of a single dominant fault-bend 280 fold in the foreland (Fig. 4c). Initially, the shortening was accommodated by uplifting and 281 overturning of the layers on the left, followed by the down-going leftmost segment being sliced 282 off the bulk rock during its clockwise rotation. At T4, F1 was initiated as a fault-propagation fold 283 with a backthrust. The décollement material was transported upwards along the thrust fault. Later 284 on, the rising décollement material penetrated through the upper décollement, accompanied with 285 amplification of the fold and the hangingwall layers being passively transported along the ramp. 286 Multiple reverse faults were formed in the forelimb of F1, i.e. hangingwall layers of the backthrust, 287 during fold tightening. At T6, F1 passed into a fault-bend fold as it continued to accumulated 288 displacement. A tensile fracture was formed in the fold hinge, and more reverse fractures were 289 generated in the forelimb of F1. Following this, F1 accommodated shortening by incremental fold 290 amplification. The tensile fracture in the fold hinge propagated downwards, with its aperture being 291 enlarged. 
293 Model 9 accommodated shortening mainly by amplification of F1 and formation of secondary

294 structures within F1. The height of the material transported from the basal décollement along the

295 hangingwall of F1 is the highest among all models (Table 1). The length of the unreformed

296 foreland is longer than the other two models in this series.

$298 \quad$ 3.4. Series 4

$299 \quad$ 3.4.1. Model 10

300 Generally, the modelling result of model 10 is rather similar to that of model 1, which is 301 characterised by successive formation of five dominant sinusoidal folds with numerous second302 order parasitic folds developed in the limbs of larger folds (Fig. 5a). A strong decoupling occurs 303 between the layers above and below the upper décollement. This is represented by the widespread 304 folding in the lower units, whilst the superficial layers remained flat and smooth. Crustal 305 thickening occurred throughout the system (Table 1), resulting in a downslope of $11.1^{\circ}$ on the 306 surface. Multiple minor diapirs rose up from the basal décollement, with a maximum height of $307 \quad 0.51 \mathrm{~km}($ Table 1$)$.

\subsubsection{Model 11}

310 The modelling result of model 11 is characterised by the formation of three dominant detachment 311 fold and five diapirs (Fig. 5b). Initially, a minor fault-propagation fold with a forethrust was 312 generated above the upper décollement. Meanwhile, folding of F1 stimulated upward movement

313 of material from the basal décollement. Following this, a minor fault-propagation fold with a 314 backthrust was developed in the forelimb of F1 above the upper décollement. Another diapir, close 315 to the core of F1, was initiated ahead of F1 and caused gentle folding of the upper layers. Later on, 
F1 and F2 constituted a larger fold through vergence towards each other. At T4, two more folds F3 and F4 were formed, which stimulated upward movement of material from the basal décollement. A fault-propagation fold with a backthrust was generated in the forelimb of F3 above the upper décollement. F3 and F4 merged into a larger fold at T6 that contains disharmonic inner units. Meanwhile, F5 was formed as a rather symmetric box fold, whose fold limbs were later cut 321 by minor thrusts.

Model 11 accommodated shortening mainly through fold growth. Notably, the system exhibits a strong structural decoupling, which is represented by (1) the disharmonic folds in the inner units of the first-order folds due to fold vergence; and (2) the secondary minor folds and thrusts 326 developed in the limbs of the deep-seated folds. The disharmonic folds significantly increase the 327 structural complexity of the system and the irregularity of the surface topography.

\subsubsection{Model 12}

330 The modelling result of model 12 is distinctively represented by the formation of piggyback thrusts that exhibit a strong deformation localisation (Fig. 5c). Initially, thrust faults were nucleated on

332 the left of the model, with the hangingwall rocks being passively transported upwards along the 333 ramp. This process was repeated for the second thrust developed ahead of the first thrust. At T3, 334 F1 was formed as a fault-propagation fold that is associated with a hinterland-dipping décollement 335 material rising from the basal décollement. As shortening continued, the hangingwall layers of the 336 early thrusts overrode the backlimb of F1, whilst the fold axes of F1 rotated clockwise. At T5, F1 337 evolved into a fault-bend fold, and the hangingwall layers of the thrust in F1 were transported 338 along the thrust ramp towards the foreland direction. At the final stage, a fault-propagation fold 
F2 with a backthrust was formed ahead of F1. Disharmonic minor fault-propagation folds were

340 generated in the limbs of F2. The accommodation of shortening was mainly achieved by the

341 piggyback thrusts, aided by the later fault-propagation fold.

\subsection{Series 5}

\subsubsection{Model 13}

345 The modelling result of model 13 is comparable to that of model 4, which is characterised by 346 successive formation of multiple sinusoidal detachment folds towards the foreland direction (Fig. 347 6a). The fold styles developed below and above the upper décollement exhibit variances, although 348 the fold traces are locally parallel. Crustal thickening occurred throughout the system (Table 1). 349 The variances in crustal thickening resulted in a downslope of the surface layer with a slope angle 350 of $9.5^{\circ}$

\subsubsection{Model 14}

Model 14 produced three dominant box folds (Fig. 6b). F1 was initiated during the rising up of a

354 hingerland-dipping décollement material from the basal décollement. This was accompanied with 355 the development of a fault-propagation fold cutting the layers in the forelimb of F1 above the upper 356 décollement. Later on, F1 experienced clockwise rotation of its forelimb and evolved into a fault357 propagation fold with a forethrust. At T4, a secondary fold was formed in the backlimb of F1, with 358 the development of a minor foreland-dipping décollement material as its core. Following this, F2 359 was formed as a rather symmetric box fold in the foreland, whose axial planes rotated clockwise and caused F2 to become asymmetric at T6. F3 was then formed between F1 and F2 as a second order detachment fold, followed by the formation of F4 in the foreland area ahead of F2. A 
362 hinterland-dipping thrust fault was formed along the right axial trace of F4 in layers above the

363 upper décollement. The system accommodated shortening by non-serial folding of the layers, 364 coupled with development of thrusts within the folds. (Table 1).

\subsubsection{Model 15}

367 The modelling result of model 15 is characterised by in-sequence development of a fault-bend fold 368 and a fault-propagation fold (Fig. 6c). Initially, a fault-bend fold was developed on the leftmost 369 side of the model. The hangingwall fragment overrode the right layers, and became overturned as 370 shortening continued, prior to the formation of F1 at T3. F1, which was initially formed as a fault371 propagation fold with a forethrust, accumulated its reverse displacement and evolved into a fault372 bend fold when the thrust reached the surface. Notably, a tensile fracture occurred in the central 373 fold hinge and propagated downward. The material rooted in the basal décollement was 374 transported towards the upper décollement at T4, which led to the anticlinal breakthrough at T7. 375 F2 was formed at T7 as a fault-propagation fold with a forethrust. A forethrust and backthrust 376 developed in the backlimb of F2 cut the layers above the upper décollement, resulting in a minor 377 pop-up structure. The system accommodated shortening mainly by fold development and also 378 accumulation of reverse displacement of F1. The undeformed area in the foreland is $5.41 \mathrm{~km}$ long 379 (Table 1).

\section{$381 \quad 3.6$. Series 6}

3.6.1. Model 16

Model 16 successively produced a series of sinusoidal detachment folds towards the foreland 384 direction (Fig. 7a). The folds below the upper décollement exhibit a lower amplitude and 
385 wavelength than the upper folds. Disharmonic folds occurred in layers above the upper 386 décollement as a result of vergence of neighbouring minor folds that subsequently constitute a 387 larger fold. Other than the disharmonic folds, the fold traces below and above the upper 388 décollement are largely parallel, and structural decoupling is less significant than that exhibited in 389 model 10 and 13. Crustal thickening occurred throughout the system (Table 1), which results in a 390 downslope angle of $13.1^{\circ}$.

391

\section{$392 \quad$ 3.6.2. Model 17}

393 The modelling result of model 17 is characterised by the formation of four dominant box folds 394 (Fig. 7b). F1 was initially formed as a symmetric box fold with its core consisting of a sub-vertical 395 diapir. The fold became tightened as shortening continued, resulting in thrust faults that propagated 396 along both the fold axial traces. Later on, the axial plane of F1 had a clockwise rotation, resulting 397 in the asymmetric geometry of F1. This was accompanied with the growth of its core material 398 along the backthrust. Secondary folds were cut by reverse faults in the forelimb of F1. F2 was 399 initiated at T3, which evolved to become a fault-propagation fold with a backthrust at T4. F2 then 400 experienced tightening and a clockwise rotation with its core steepened. During T4 and T5, two 401 minor secondary folds F3 and F4 occurred on the left of F1 and F4, respectively. This was followed 402 by the development of F5 at T6, and F6 at T7, both of which are fault-propagation fold with a 403 forethrust. At T7 a minor diapir was initiated between F4 and F5, and caused gentle folding of the 404 host layer, whilst the layers above the upper décollement were not influenced. Crustal shortening 405 was mainly accommodated by in-sequence development of four dominant folds and non-serial 406 formation of some minor diapirs. 
Model 18 produced a concave-up pop-up structure that consists of an early-formed faultpropagation fold with a backthrust, and a later fault-bend fold with a forethrust (Fig. 7c). The

411 geometry of the pop-up structure is similar to that described by Alsop et al. (2017). F1 was initiated

412 at T2 as a fault-propagation fold, and its fold axis subsequently experienced a clockwise rotation.

413 Notably, its core material penetrated the upper décollement at T4, whilst the forelimb of F1 was

414 cut by a thrust fault developed along the axial trace. At T5, F2 was formed with the décollement

415 material intruding upward along the forethrust. A backthrust was developed along fold axial trace

416 when F2 became tightened as shortening continued. At T7, F2 evolved into a fault-bend fold as it

417 accumulated reverse displacement, with a tensile fracture occurring in its hinge zone. Interestingly,

418 F1 and F2 converged towards each other, which finally constituted a pop-up structure. The system

419 accommodated shortening mainly by the pop-up structure, which is tightly associated with

420 development of the two major thrusts. The undeformed area is $5.16 \mathrm{~km}$ long in the foreland (Table

421 1).

422

$423 \quad 3.7$. Summary of modelling results

424 3.7.1. Models with the same mechanical property

425 Models that are composed of the least competent material 1, exhibit similar structural styles, which 426 are characterised by multiple short-wavelength, sinusoidal detachment folds (Fig. 8). The weak 427 material rooted in the basal décollement are much smaller than those in models composed of more 428 competent materials. Shortening of the system resulted in crustal thickening across the entire 429 section, resulting in a clear taper towards the foreland direction. Models that are composed of more 430 competent material 2, all produced asymmetric box folds, with weak material from the décollement 
431 filling the core region of the folds. The fold limbs are commonly faulted. Models that are

432 composed of the most competent material 3, are dominated by thrusts, fault-bend folds and pop-

433 up structures. Strain localisation, represented by piggyback arrangement of forethrust and

434 progressive accumulation of fault displacement during shortening, is distinct. Tensile fractures

435 commonly occurred in fold hinge zones.

436

437 Structural decoupling between stratigraphic units above and below the upper décollement is the

438 most profound in models composed of the least competent material 1, followed by those composed

439 of more competent material 2. Models that are composed of the most competent material 3 exhibit

440 the least features of structural decoupling.

441

$442 \quad 3.7 .2$. Models with the same depth of the upper and lower décollement

443 Models with the shallowest upper décollement exhibit the most significant structural decoupling 444 above and below the upper décollement (Fig. 8). This is represented by the fact that the underlying,

445 deep-rooted structures did not significantly affect the upper layers in models 1 and 10 with 446 incompetent materials, and also represented by minor disharmonic folds and reverse faults 447 developed above the upper décollement in other models. Pop-up structures that only occurred in 448 the upper units also contributed to structural decoupling. Structural decoupling is much less 449 common in models with a deeper upper décollement.

450

\section{$451 \quad 3.7 .3$. Models with the same thickness of the upper décollement}

452 Generally, models (10-18) with equally thick décollements exhibit a more significant structural 453 decoupling below and above the upper décollements (Fig. 8). Moreover, a thicker upper 
454 décollement tends to hinder vertical propagation of folds, and to promote lateral development of 455 structures. This is evident by a larger number of folds and rising décollement material developed 456 in models in which the thickness of the upper and lower décollement are the same than models 457 with a thinner upper décollement.

459 4. Discussion

460 This section is focused on the discussion of the controls of rock mechanical property, depth and 461 thickness of the upper décollement on structural styles and decoupling in FAT belts, followed by 462 a comparison of the modelling results to the Zagros FAT belt that contains multiple décollements.

\subsection{Controls on structural styles}

465 The final configuration of the thin-skinned fold belts produced in our models is represented by the 466 formation of sinusoidal detachment folds, box folds, fault-propagation folds, fault-bend folds, pop467 up structures, tensile fractures and piggyback thrusts (Fig. 8). Given the predefined boundary and 468 initial conditions of the six series of models, it is possible to evaluate the geologic controls on the 469 competing mechanisms of folding versus faulting that gave rise to the styles of deformation in the 470 systems.

471

472 Each series of models, with the same boundary and initial conditions except bonding cohesion, 473 exhibit significantly different structural styles, which can be represented by (1) models with the 474 least competent material are dominated by short-wavelength, sinusoidal and disharmonic 475 detachment folds; (2) models with a more competent material are dominated by faulted box folds; 476 and (3) models with the most competent material are dominated by thrusts, fault-bend folds and 
477 tensile fractures. This indicates that rock mechanical property plays a dominant role in controlling

478 structural styles, agreeing with Morgan (2015) and Meng and Hodgetts (2019).

479

480 The depth of the upper décollement has a major influence on the fold dominated systems, where a

481 deeper upper décollement favours a shorter wavelength of the folds developed below the

482 décollement. In contrast, a shallower upper décollement allows the deep-seated folds in the lower

483 units to amplify and to attain a larger wavelength. For systems dominated by thrusts, structural

484 styles are also significantly influenced by the depth of the upper décollement, i.e. a shallower upper 485 décollement promotes transportation of hangingwall layers along the ramps of piggback 486 forethrusts (dip between $24^{\circ}$ and $41^{\circ}$ ) through accumulation of fault displacement, whilst a deeper 487 upper décollement favours formation of backthrusts (dip between $34^{\circ}$ and $60^{\circ}$ ) (Fig. $4 \mathrm{c}$ ) or a 488 combination of backthrusts and forethrusts (dip between $39^{\circ}$ and $41^{\circ}$ ) (model 18) (Fig. 7c) to 489 accommodate shortening.

490

491 The different modelling results of models with varied upper décollement thickness suggest that 492 the thickness of the upper décollement is one of the factors that determined the structures produced 493 within the systems. Such differences may be attributed to the fact that the upper décollement 494 separates the upper units from the lower units and hindered vertical growth of folds by 495 redistribution of weak décollement materials onto synclines. Moreover, a thicker upper 496 décollement is more likely to cause the formation of minor structures in the upper units, e.g. fault497 propagation folds and pop-up structures, especially in systems with a shallow upper décollement. 498 This is possible because that flow of weak materials and the resulting thickness variation is more 
common in a thicker upper décollement during shortening, which can support fold development by material redistribution into fold cores as suggested by Stewart (1996).

\subsection{Controls on structural decoupling}

Our modelling results reveal that the models composed of the least competent material, exhibit the most significant structural decoupling above and below the upper décollement. This is represented by the fact that folds were formed disharmonically above the below the upper décollement (Fig. 8). Moreover, such materials promoted forward propagation of deformation and a more distributed strain rather than amplification of existing structures, which resulted in crustal thickening across the entire section (Table 1). The simple surface structures mask complex folds at depth. Conversely, models that are composed of more competent materials promoted vertical growth of structures and strain localisation. This favoured similar folding in the upper and lower units, and hence contributed to structural coupling.

\section{Another major control on structural decoupling is the depth of the upper décollement. The} modelling results presented indicate that a shallow upper décollement favours the formation of minor parasitic structures in the limbs of deep-seated folds with a broad wavelength, and also popup structures in the superficial layers. In contrast, traces of folds above and below the upper décollement tend to be more parallel if the upper décollement is deeper. Hence, the shallower the upper décollement is, the higher the degree of structural decoupling will become.

The thickness of the upper décollement also played an important role in structural decoupling in our models. It is shown that a thicker upper décollement inhibited the upward growth of folds 
522 either through local thinning of the décollement layer on top of anticline hinge zones, or thickening

523 above fold limbs (Fig. 5a). Moreover, a thicker upper décollement provided sufficient materials to

524 fill cores of disharmonic folds formed above the upper décollement during material redistribution

525 (Fig. 5b). Such features are much less distinctive in models with a thinner upper décollement.

\subsection{Comparison to the Zagros Fold-and-Thrust Belt}

Although the models presented are not aimed for directly simulating structures of any natural prototypes, here it is attempted to compare the modelling results to the Zagros FAT Belt with multidécollements. The Zagros FAT Belt is a NW-SE-trending, $1800 \mathrm{~km}$ long segment of the Alpine-Himalayan orogenic belt (Fig. 9a), which has been extensively studied not only because that it is one of the most active collisional belts worldwide (Sella et al., 2002; Pirouz et al., 2017), but also due to its specular fold trains developed in a thick multilayer of Paleozoic to Cenozoic

534 sediments that serve as the host to one of the world's largest hydrocarbon provinces (Cooper, 2007).

535 There are three prominent décollement levels within the sedimentary sequence. These are the 536 Hormuz Formation, the Dashtak Formation and the Gashsaran Formation, which significantly 537 affected the mechanical stratigraphy and rock rheology profile of the Zagros FAT Belt (Sepehr et 538 al., 2006) (Fig. 9). The Early Cambrian Hormuz evaporites serves as the basal décollement for the 539 fold trains to be detached on (Bahroudi and Koyi, 2003). The middle Miocene evaporites of the 540 Gashsaran Formation constitute a relatively shallow upper décollement in the Dezful area (Fig. 9b) 541 (Ghanadian et al., 2017b). The Triassic evaporites of the Dashtak Formation is one of the major 542 intermediate décollements in coastal Fars and southwestern Izeh (Fig. 11b) (Najafi et al., 2014).

543 The three major décollements significantly affected the mechanical stratigraphy and rock rheology 544 profile of Zagros (Sepehr et al., 2006) (Fig. 9b). 
546 In the Zagros FAT Belt, most of the shortening of the sedimentary cover has been accommodated

547 by multilayer detachment folding and Hormuz salt diapirism (Motamedi et al., 2011; Yamato et

548 al., 2011; Najafi et al., 2018). The Gachsaran evaporites have been suggested to have enabled 549 decoupling the surface structures and the deep-seated folds in areas where the evaporites act as the 550 upper décollement (Sherkati et al., 2005; Fard et al., 2006, 2011; Mouthereau et al., 2007; 551 Ghanadian et al., 2017b; Derikvand et al., 2018, 2019; Najafi et al., 2018) (Fig. 9b). Structural 552 decoupling is represented by (1) flow of mobile salt onto underlying synclines (Sherkati and 553 Letouzey, 2004; Ghanadian et al., 2017a); (2) formation of strongly disharmonic, short-wavelength 554 detachment folds above the Gachsaran Formation (Fig. 9c); and (3) termination of some deep555 seated thrust faults that encounter the Gachsaran evaporites, and development of minor thrust 556 faults that are originated from the Gachsaran Formation (Ghanadian et al., 2017b). Notably, 557 structural decoupling controlled by the Gachsaran evaporites becomes less considerable in the NE 558 sector compared to the SW sector of Deful, due to the decrease in its thickness (Derikvand et al., 559 2018). The conclusions drawn above largely agree with our modelling results that a shallower and 560 thicker upper décollement contributes to a more profound structural decoupling, especially to the 561 generation of secondary disharmonic folds and thrusts in the shallow strata that do not coincide 562 with the deep-seated structures (Figs 2b, 5b).

563

564 The Triassic evaporites of the Dashtak Formation is identified as the main intermediate 565 décollement that effectively shaped the folds in the Fars region (Fig. 9b). The folds developed 566 there mainly include asymmetric faulted box folds. Notably, the fold traces in strata below and 567 above the Dashtak evaporites are approximately parallel, indicating a less degree of structural 
568 decoupling than that in the Dezful Embayment. The relatively 'simple' structural styles in the Fars

569 (Blanc et al., 2003) are similar to our modeling results of models 5 and 14 with an intermediate-

570 depth upper décollement. In particular, structural decoupling in the two models is less significant

571 than models with a shallower upper décollement.

572

573 It should be noted that the numerical models presented are highly simplified and only show the

574 first order structural similarities to the Zagros FAT Belt. To better reproduce the structures

575 developed in this area, it is suggested that future models should incorporate more comprehensive

576 regional geological data and other important factors, such as the critical taper, décollement dip and

577 erosion (Van Tuyl et al., 2015; Alves et al., 2017) that are not considered in this study.

578

\section{5. Conclusions}

580 This study uses the discrete element method to simulate thin-skinned tectonic deformation in 581 stratigraphic sequences with double décollements, to yield new insights into the combined control 582 of rock competence, depth and thickness of the upper décollement on structural styles and 583 decoupling characteristics. We conclude the following:

(1) The models with double décollements and varying parameters produced a range of structural styles as the result of shortening, including sinusoidal detachment folds in models composed of the least competent material, faulted box folds in models composed of a more competent material, and thrust-dominated piggyback thrust systems and pop-up structures in models composed of the most competent material. 
601

602

\section{References}

(2) Structural decoupling above and below the upper décollements decreases as rock competence increases. A shallower upper décollement favours the development of minor disharmonic folds and pop-up structures as second-order structures that do not coincide with the deep-seated folds. A thicker upper décollement contributes to the generation of more disharmonic minor folds in the shallow strata by providing sufficient mobile materials to fill fold cores, and remobilization of materials onto synclines, both enhancing structural decoupling.

(3) Our modeling results exhibit first-order structural similarities to the predominant diapircored box folds in the Zagros Fold-and-Thrust Belt with multidécollements.

(4) This study demonstrates that rock competence, depth and thickness of the upper décollement can jointly influence thin-skinned tectonics in systems with multiple décollement levels, and determine the degree of structural decoupling.

\section{Acknowledgements}

The first author's position is funded by the Sandstone Injection Research Group (SIRG) consortium. Itasca is thanked for technical support. Google Earth ${ }^{\mathrm{TM}}$ is acknowledged for providing satellite images. We thank Ian Alsop for editorial handling of this paper. The thorough and constructive comments by John Cosgrove and Tiago M. Alves are greatly appreciated. 
Alsop, G.I., Marco, S., Weinberger, R., Levi, T., 2017. Upslope-verging back thrusts developed during downslope-directed slumping of mass transport deposits. Journal of Structural Geology 100, 45-61.

Alves, T.M., Fetter, M., Lima, C., Cartwright, J.A., Cosgrove, J., Gangá, A., Queiroz, C.L. Strugale, M., 2017. An incomplete correlation between pre-salt topography, top reservoir erosion, and salt deformation in deep-water Santos Basin (SE Brazil). Marine and Petroleum Geology 79, 300-320.

Bahroudi, A., Koyi, H., 2003. Effect of spatial distribution of Hormuz salt on deformation style in the Zagros fold and thrust belt: an analogue modelling approach. Journal of the Geological Society 160, 719-733.

Benesh, N.P., Plesch, A., Shaw, J.H., Frost, E.K., 2007. Investigation of growth fault bend folding using discrete element modeling: Implications for signatures of active folding above blind thrust faults. Journal of Geophysical Research: Solid Earth 112, B03S04, doi:10.1029/2006JB004466.

Blanc, E.-P., Allen, M.B., Inger, S., Hassani, H., 2003. Structural styles in the Zagros simple folded zone, Iran. Journal of the Geological Society 160, 401-412.

Blay, P., Cosgrove, J.W., Summers, J.M., 1977. An experimental investigation of the development of structures in multilayers under the influence of gravity. Journal of the Geological Society $133,329-342$.

Bonini, M., 2003. Detachment folding, fold amplification, and diapirism in thrust wedge experiments. Tectonics 22, 1065, doi:10.1029/2002TC001458. 
634 Borderie, S., Graveleau, F., Witt, C., Vendeville, B.C., 2018. Impact of an interbedded viscous

635

636

637

638

639

640

641

642

643

644

645

646

647

648

649

650

651

652

653

654

655

656 décollement on the structural and kinematic coupling in fold-and-thrust belts: Insights from analogue modeling. Tectonophysics 722, 118-137.

Burbidge, D.R., Braun, J., 2002. Numerical models of the evolution of accretionary wedges and fold-and-thrust belts using the distinct-element method. Geophysical Journal International 148, 542-561.

Callot, J.-P., Trocmé, V., Letouzey, J., Albouy, E., Jahani, S., Sherkati, S., 2012. Pre-existing salt structures and the folding of the Zagros Mountains. Geological Society, London, Special Publications 363, 545-561.

Cardozo, N., Allmendinger, R.W., Morgan, J.K., 2005. Influence of mechanical stratigraphy and initial stress state on the formation of two fault propagation folds. Journal of Structural Geology 27, 1954-1972.

Casciello, E., Vergés, J., Saura, E., Casini, G., Fernández, N., Blanc, E., Homke, S., Hunt, D.W., 2009. Fold patterns and multilayer rheology of the Lurestan Province, Zagros simply folded belt (Iran). Journal of the Geological Society 166, 947-959.

Chapple, W.M., 1978. Mechanics of thin-skinned fold-and-thrust belts. Geological Society of America Bulletin 89, 1189-1198.

Cooper, M., 2007. Structural style and hydrocarbon prospectivity in fold and thrust belts: a global review. Geological Society, London, Special Publications 272, 447-472.

Cundall, P.A., Strack, O.D.L., 1979. A discrete numerical model for granular assemblies. Geotechnique 29, 47-65.

Cundall, P.A., Strack, O.D.L., 1999. Particle flow code in 2 dimensions. Itasca consulting group, Inc. 
657 Davis, D.M., Engelder, T., 1985. The role of salt in fold-and-thrust belts. Tectonophysics 119, 67-

658

659

660

661

662

663

664

665

666

667

668

669

670

671

672

673

674

675

676

677
88.

Dean, S.L., Morgan, J.K., Fournier, T., 2013. Geometries of frontal fold and thrust belts: Insights from discrete element simulations. Journal of Structural Geology 53, 43-53.

Derikvand, B., Alavi, S.A., Fard, I.A., Hajialibeigi, H., 2018. Folding style of the Dezful Embayment of Zagros Belt: Signatures of detachment horizons, deep-rooted faulting and syn-deformation deposition. Marine and Petroleum Geology 91, 501-518.

Derikvand, B., Alavi, S.A., Fard, I.A., Jalali, L., 2019. Changing in fold geometry from faulted detachment fold to fault-bend fold, a case study: The Zeloi Anticline in the Dezful Embayment, southwest of Iran. Journal of Petroleum Science and Engineering 173, 381401.

Driehaus, L., Nalpas, T., Ballard, J.-F., 2014. Interaction between deformation and sedimentation in a multidecollement thrust zone: Analogue modelling and application to the SubAndean thrust belt of Bolivia. Journal of Structural Geology 65, 59-68.

Erickson, S.G., 1996. Influence of mechanical stratigraphy on folding vs faulting. Journal of Structural Geology 18, 443-450.

Fard, I.A., Braathen, A., Mokhtari, M., Alavi, S.A., 2006. Interaction of the Zagros Fold-Thrust Belt and the Arabian-type, deep-seated folds in the Abadan Plain and the Dezful Embayment, SW Iran. Petroleum Geoscience 12, 347-362.

Fard, I.A., Sepehr, M., Sherkati, S., 2011. Neogene salt in SW Iran and its interaction with Zagros folding. Geological Magazine 148, 854-867. 
678 Farzipour-Saein, A., Yassaghi, A., Sherkati, S., Koyi, H., 2009. Mechanical stratigraphy and

679

680

681

682

683

684

685

686

687

688

689

690

691

692

693

694

695

696

697

698

699 folding style of the Lurestan region in the Zagros Fold-Thrust Belt, Iran. Journal of the Geological Society 166, 1101-1115.

Farzipour-Saein, A., Koyi, H., 2016. Intermediate decollement activation in response to the basal friction variation and its effect on folding style in the Zagros fold-thrust belt, an analogue modeling approach. Tectonophysics 687, 56-65.

Feng, L., Bartholomew, M.J., Choi, E., 2015. Spatial arrangement of décollements as a control on the development of thrust faults. Journal of Structural Geology 75, 49-59.

Finch, E., Hardy, S., Gawthorpe, R., 2003. Discrete element modelling of contractional faultpropagation folding above rigid basement fault blocks. Journal of Structural Geology 25, $515-528$.

Finch, E., Hardy, S., Gawthorpe, R., 2004. Discrete-element modelling of extensional faultpropagation folding above rigid basement fault blocks. Basin Research 16, 467-488.

Gee, E.R., Gee, D.G., 1989. Overview of the geology and structure of the Salt Range, with observations on related areas of northern Pakistan. Geological Society of America Special Papers 232, 95-112.

Ghanadian, M., Faghih, A., Fard, I.A., Kusky, T., Maleki, M., 2017a. On the role of incompetent strata in the structural evolution of the Zagros Fold-Thrust Belt, Dezful Embayment, Iran. Marine and Petroleum Geology 81, 320-333.

Ghanadian, M., Faghih, A., Fard, I.A., Grasemann, B., Soleimany, B., Maleki, M., 2017b. Tectonic constraints for hydrocarbon targets in the Dezful Embayment, Zagros Fold and Thrust Belt, SW Iran. Journal of Petroleum Science and Engineering 157, 1220-1228. 
Ghanadian, M., Faghih, A., Grasemann, B., Fard, I.A., Maleki, M., 2017c. Analogue modeling of the role of multi-level decollement layers on the geometry of orogenic wedge: an application to the Zagros Fold-Thrust Belt, SW Iran. International Journal of Earth Sciences 106, 2837-2853.

Ghazian, R.K., Buiter, S.J.H., 2014. Numerical modelling of the role of salt in continental collision: an application to the southeast Zagros fold-and-thrust belt. Tectonophysics 632, 96-110.

Hardy, S., Finch, E., 2005. Discrete-element modelling of detachment folding. Basin Research 17, 507-520.

Hardy, S., Finch, E., 2006. Discrete element modelling of the influence of cover strength on basement-involved fault-propagation folding. Tectonophysics 415, 225-238.

Hardy, S., Finch, E., 2007. Mechanical stratigraphy and the transition from trishear to kink-band fault-propagation fold forms above blind basement thrust faults: a discrete-element study. Marine and Petroleum Geology 24, 75-90.

Hardy, S., 2018. Discrete element modelling of extensional, growth, fault-propagation folds. Basin Research, doi: 10.1111/bre.12335.

Hughes, A.N., Benesh, N.P., Shaw, J.H., 2014. Factors that control the development of fault-bend versus fault-propagation folds: Insights from mechanical models based on the discrete element method (DEM). Journal of Structural Geology 68, 121-141.

Izquierdo-Llavall, E., Roca, E., Xie, H., Pla, O., Muñoz, J.A., Rowan, M.G., Yuan, N., Huang, S., 2018. Influence of Overlapping décollements, Syntectonic Sedimentation, and Structural Inheritance in the Evolution of a Contractional System: The Central Kuqa Fold-andThrust Belt (Tian Shan Mountains, NW China). Tectonics 37, 2608-2632. 
Jahani, S., Hassanpour, J., Mohammadi-Firouz, S., Letouzey, J., de Lamotte, D.F., Alavi, S.A., Soleimany, B., 2017. Salt tectonics and tear faulting in the central part of the Zagros FoldThrust Belt, Iran. Marine and Petroleum Geology 86, 426-446.

Jaumé, S.C., Lillie, R.J., 1988. Mechanics of the Salt Range-Potwar Plateau, Pakistan: A foldand-thrust belt underlain by evaporites. Tectonics 7, 57-71.

Leturmy, P., Mugnier, J.L., Vinour, P., Baby, P., Colletta, B., Chabron, E., 2000. Piggyback basin development above a thin-skinned thrust belt with two detachment levels as a function of interactions between tectonic and superficial mass transfer: the case of the Subandean Zone (Bolivia). Tectonophysics 320, 45-67.

Liu, Y., Konietzky, H., 2018. Particle-Based Modeling of Pull-Apart Basin Development. Tectonics 37, 343-358.

Massoli, D., Koyi, H.A., Barchi, M.R., 2006. Structural evolution of a fold and thrust belt generated by multiple décollements: analogue models and natural examples from the Northern Apennines (Italy). Journal of Structural Geology 28, 185-199.

McQuarrie, N., 2004. Crustal scale geometry of the Zagros fold-thrust belt, Iran. Journal of Structural Geology 26, 519-535.

Meng, Q., Hodgetts, D., 2019. Combined control of décollement layer thickness and cover rock cohesion on structural styles and evolution of fold belts: A discrete element modelling study. Tectonophysics 757, 58-67.

Morgan, J.K., 2015. Effects of cohesion on the structural and mechanical evolution of fold and thrust belts and contractional wedges: Discrete element simulations. Journal of Geophysical Research: Solid Earth 120, 3870-3896. 
Motamedi, H., Sepehr, M., Sherkati, S., Pourkermani, M., 2011. Multi-phase Hormuz salt diapirism in the southern Zagros, SW Iran. Journal of Petroleum Geology 34, 29-43.

Motamedi, H., Sherkati, S., Sepehr, M., 2012. Structural style variation and its impact on hydrocarbon traps in central Fars, southern Zagros folded belt, Iran. Journal of Structural Geology 37, 124-133.

Mouthereau, F., Tensi, J., Bellahsen, N., Lacombe, O., De Boisgrollier, T., Kargar, S., 2007. Tertiary sequence of deformation in a thin-skinned/thick-skinned collision belt: The Zagros Folded Belt (Fars, Iran). Tectonics 26, TC5006, doi:10.1029/2007TC002098.

Najafi, M., Yassaghi, A., Bahroudi, A., Vergés, J., Sherkati, S., 2014. Impact of the Late Triassic Dashtak intermediate detachment horizon on anticline geometry in the Central Frontal Fars, SE Zagros fold belt, Iran. Marine and Petroleum Geology 54, 23-36.

Najafi, M., Vergés, J., Etemad-Saeed, N., Karimnejad, H.R., 2018. Folding, thrusting and diapirism: Competing mechanisms for shaping the structure of the north Dezful Embayment, Zagros, Iran. Basin Research 30, 1200-1229.

Naylor, M., Sinclair, H.D., Willett, S., Cowie, P.A., 2005. A discrete element model for orogenesis and accretionary wedge growth. Journal of Geophysical Research: Solid Earth 110, B12403, doi:10.1029/2003JB002940.

Pirouz, M., Avouac, J.-P., Hassanzadeh, J., Kirschvink, J.L., Bahroudi, A., 2017. Early Neogene foreland of the Zagros, implications for the initial closure of the Neo-Tethys and kinematics of crustal shortening. Earth and Planetary Science Letters 477, 168-182.

Ruh, J.B., Kaus, B.J.P., Burg, J.P., 2012. Numerical investigation of deformation mechanics in fold-and-thrust belts: Influence of rheology of single and multiple décollements. Tectonics 31, TC3005,doi:10.1029/2011TC003047. 
Ruh, J.B., Gerya, T., Burg, J.-P., 2017. Toward 4D modeling of orogenic belts: Example from the transpressive Zagros Fold Belt. Tectonophysics 702, 82-89.

Schori, M., Mosar, J., Schreurs, G., 2015. Multiple detachments during thin-skinned deformation of the Swiss Central Jura: a kinematic model across the Chasseral. Swiss Journal of Geosciences 108, 327-343.

Sella, G.F., Dixon, T.H., Mao, A., 2002. REVEL: A model for recent plate velocities from space geodesy. Journal of Geophysical Research: Solid Earth 107, NO. B4, 2081, 10.1029/2000JB000033.

Sepehr, M., Cosgrove, J., Moieni, M., 2006. The impact of cover rock rheology on the style of folding in the Zagros fold-thrust belt. Tectonophysics 427, 265-281.

Sherkati, S., Letouzey, J., 2004. Variation of structural style and basin evolution in the central Zagros (Izeh zone and Dezful Embayment), Iran. Marine and petroleum geology 21, 535554.

Sherkati, S., Molinaro, M., de Lamotte, D.F., Letouzey, J., 2005. Detachment folding in the Central and Eastern Zagros fold-belt (Iran): salt mobility, multiple detachments and late basement control. Journal of Structural Geology 27, 1680-1696.

Sherkati, S., Letouzey, J., Frizon de Lamotte, D., 2006. Central Zagros fold-thrust belt (Iran): New insights from seismic data, field observation, and sandbox modeling. Tectonics 25, TC4007, doi:10.1029/2004TC001766.

Sommaruga, A., 1999. Décollement tectonics in the Jura forelandfold-and-thrust belt. Marine and Petroleum Geology 16, 111-134.

Stewart, S.A., 1996. Influence of detachment layer thickness on style of thin-skinned shortening. Journal of Structural Geology 18, 1271-1274. 
790 Stewart, S. A., 1999. Geometry of thin-skinned tectonic systems in relation to detachment layer 791 thickness in sedimentary basins. Tectonics 18, 719-732.

792 Tavani, S., Cifelli, F., 2010. Deformation pattern analysis and tectonic implications of a 793 décollement level within the Central Apennines (Italy). Geological Journal 45, 582-596.

794 Van Tuyl, J., Alves, T. M., Moore, G. F., 2015. Strain decoupling reveals variable seismogenic 795 796 risk in SE Japan (Nankai Trough). Geochemistry, Geophysics, Geosystems 16, 20252037.

797 Vergés, J., Goodarzi, M.G.H., Emami, H., Karpuz, R., Efstathiou, J., Gillespie, P., 2011. Multiple 798 detachment folding in Pusht-e Kuh arc, Zagros: Role of mechanical stratigraphy. AAPG 799 Memoir 94, 69-94.

800 Vidal-Royo, O., Hardy, S., Muñoz, J.A., 2011. The roles of complex mechanical stratigraphy and 801 syn-kinematic sedimentation in fold development: insights from discrete-element 802 modelling and application to the Pico del Águila anticline (External Sierras, Southern 803 Pyrenees). Geological Society, London, Special Publications 349, 45-60.

804 Wang, X., Guan, J.S.S., Hubert-Ferrari, A., Jia, R.G.-M.C., 2011. Cenozoic structure and tectonic 805 evolution of the Kuqa fold belt, southern Tianshan, China. AAPG Memoir 94, 215-243. 806 Yamato, P., Kaus, B.J.P., Mouthereau, F., Castelltort, S., 2011. Dynamic constraints on the crustal807 scale rheology of the Zagros fold belt, Iran. Geology 39, 815-818. 
Table 1. Summary of modelling results of the discrete element models.

\begin{tabular}{|c|c|c|c|c|c|c|c|c|c|c|}
\hline \multirow{2}{*}{$\begin{array}{l}\text { Model } \\
\text { series }\end{array}$} & \multirow[t]{2}{*}{ Number } & \multirow{2}{*}{$\begin{array}{c}\text { Relative } \\
\text { depth of the } \\
\text { upper } \\
\text { décollement }\end{array}$} & \multirow{2}{*}{$\begin{array}{l}\text { Relative } \\
\text { thickness of } \\
\text { the upper } \\
\text { décollement }\end{array}$} & \multicolumn{2}{|c|}{$\begin{array}{c}\text { Fold core filled } \\
\text { by décollement } \\
\text { material }\end{array}$} & \multicolumn{2}{|c|}{$\begin{array}{l}\text { Surface } \\
\text { uplift } \\
(\mathrm{km})\end{array}$} & \multirow{2}{*}{$\begin{array}{l}\text { Length of } \\
\text { undeformed } \\
\text { foreland } \\
\quad(\mathrm{km})\end{array}$} & \multirow[t]{2}{*}{ Structural styles } & \multirow{2}{*}{$\begin{array}{c}\text { Distinct } \\
\text { structural } \\
\text { decoupling, } \\
\text { Y/N }\end{array}$} \\
\hline & & & & Number & $\begin{array}{l}\text { Height } \\
(\mathrm{km})\end{array}$ & Min. & Max. & & & \\
\hline \multirow{3}{*}{$\mathrm{S} 1$} & 1 & shallow & thinner & 8 & 0.48 & 1.13 & 1.63 & 0 & sinusoidal folds, box folds, & $\mathrm{Y}$ \\
\hline & 2 & shallow & thinner & 4 & 1.13 & 0 & 1.79 & 2.20 & box fold & $\mathrm{Y}$ \\
\hline & 3 & shallow & thinner & 3 & 1.36 & 0 & 3.10 & 5.67 & piggyback thrusts & $\mathrm{Y}$ \\
\hline \multirow{3}{*}{$\mathrm{S} 2$} & 4 & intermediate & thinner & 8 & 0.37 & 0.30 & 1.87 & 0 & sinusoidal folds, box folds, & $\mathrm{Y}$ \\
\hline & 5 & intermediate & thinner & 4 & 1.49 & 0 & 1.85 & 2.33 & box folds, fault-propagation folds & $\mathrm{N}$ \\
\hline & 6 & intermediate & thinner & 4 & 1.89 & 0 & 2.75 & 5.26 & piggyback thrusts, fault-bend folds & $\mathrm{N}$ \\
\hline \multirow{3}{*}{$\mathrm{S} 3$} & 7 & deep & thinner & 11 & 0.42 & 0.29 & 1.82 & 0 & sinusoidal folds & $\mathrm{Y}$ \\
\hline & 8 & deep & thinner & 3 & 1.59 & 0 & 1.72 & 4.46 & box fold, fault-propagation fold & $\mathrm{N}$ \\
\hline & 9 & deep & thinner & 1 & 2.94 & 0 & 2.49 & 6.04 & fault-bend fold, tensile fractures & $\mathrm{N}$ \\
\hline \multirow{3}{*}{$\mathrm{S} 4$} & 10 & shallow & equal & 7 & 0.51 & 0.27 & 1.84 & 0 & box folds, sinusoidal folds & $\mathrm{Y}$ \\
\hline & 11 & shallow & equal & 6 & 1.09 & 0 & 1.93 & 1.87 & box folds & $\mathrm{Y}$ \\
\hline & 12 & shallow & equal & 2 & 1.66 & 0 & 4.68 & 5.37 & piggyback thrusts, fault-propagation fold & $\mathrm{Y}$ \\
\hline \multirow{3}{*}{ S5 } & 13 & intermediate & equal & 8 & 0.35 & 0.27 & 1.85 & 0 & sinusoidal folds, box folds & $\mathrm{Y}$ \\
\hline & 14 & intermediate & equal & 4 & 1.44 & 0 & 1.95 & 2.24 & box folds & $\mathrm{N}$ \\
\hline & 15 & intermediate & equal & 2 & 2.11 & 0 & 3.15 & 5.41 & $\begin{array}{l}\text { fault-propagation and bend folds, tensile } \\
\text { fractures }\end{array}$ & $\mathrm{N}$ \\
\hline \multirow{3}{*}{ S6 } & 16 & deep & equal & 5 & 0.37 & 0.24 & 2.11 & 0 & sinusoidal folds, box folds & $\mathrm{Y}$ \\
\hline & 17 & deep & equal & 3 & 1.56 & 0 & 1.99 & 1.13 & box folds, fault-propagation folds & $\mathrm{N}$ \\
\hline & 18 & deep & equal & 2 & 1.93 & 0 & 2.91 & 5.16 & $\begin{array}{l}\text { fault-propagation and bend folds, tensile } \\
\text { fractures }\end{array}$ & $\mathrm{N}$ \\
\hline
\end{tabular}




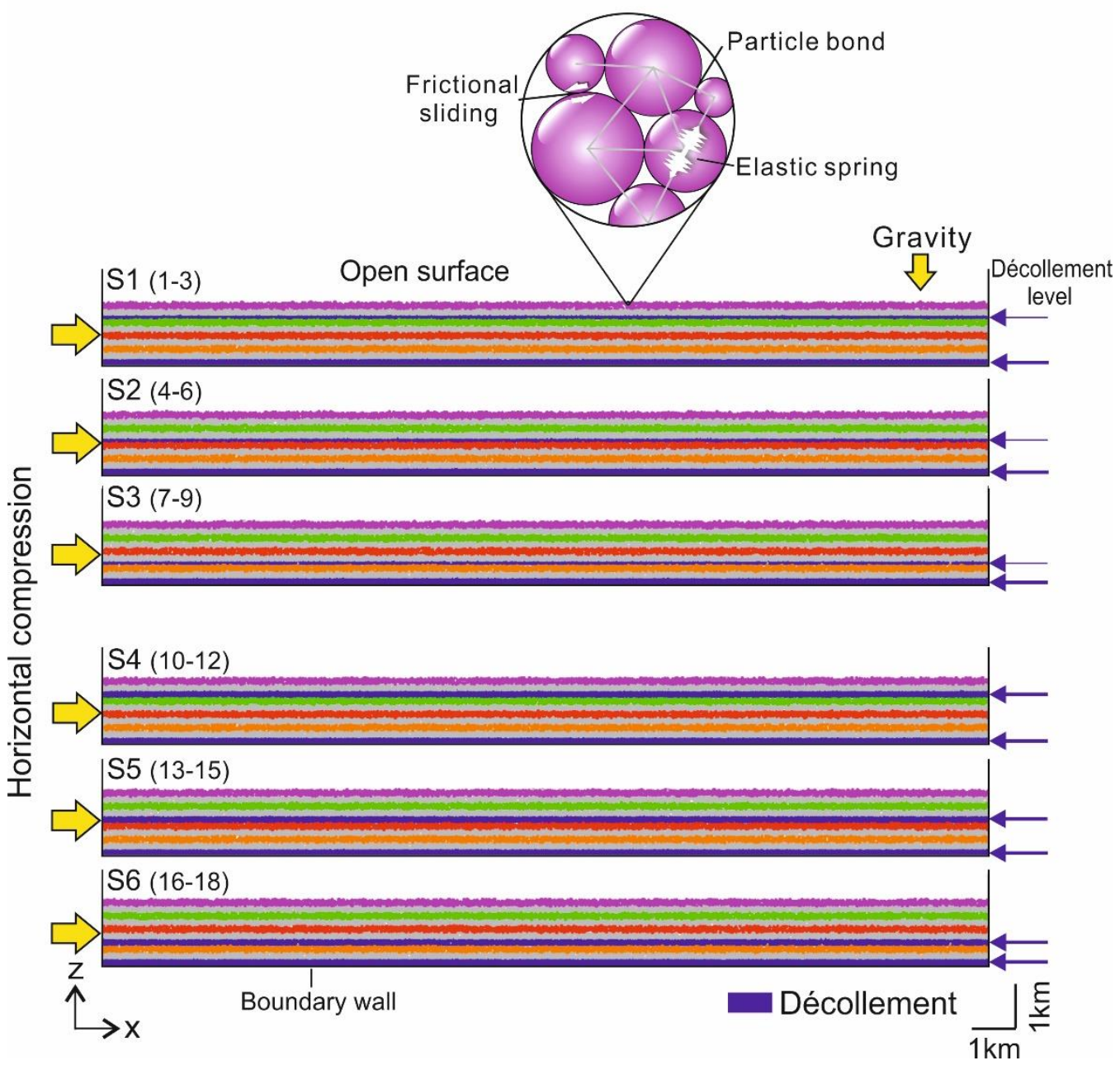

Fig. 1. (a) Design and boundary conditions of the discrete element models. Models of series 1-3 contain a thinner upper décollement than the basal décollement. Models of series 4-6 contain two equally thick décollements. The enlarged circular area shows particle interactions. 
(a)
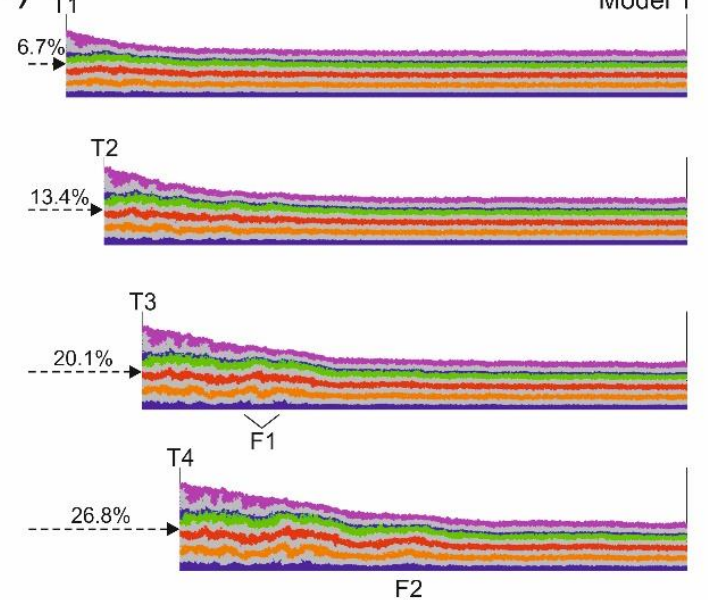

T5

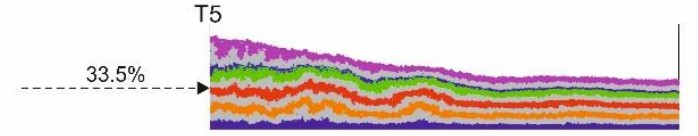

T6

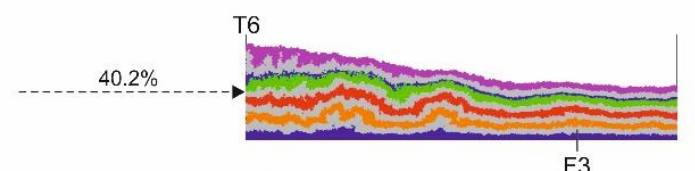

T7

$46.9 \%$ (b)
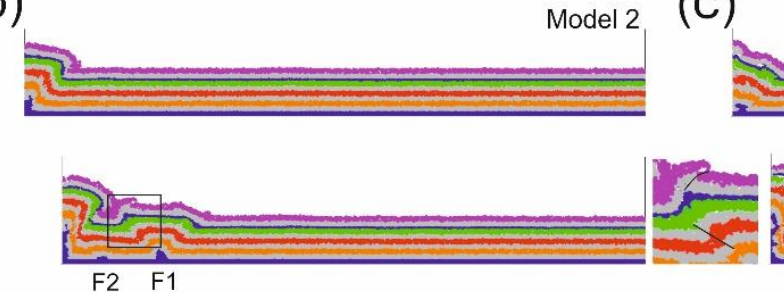

1
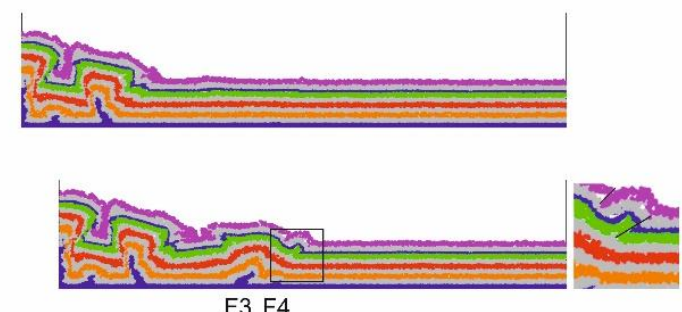

F3 F4
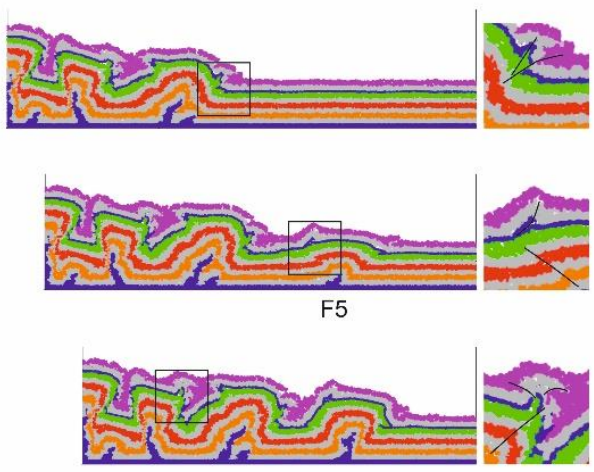

Model 3
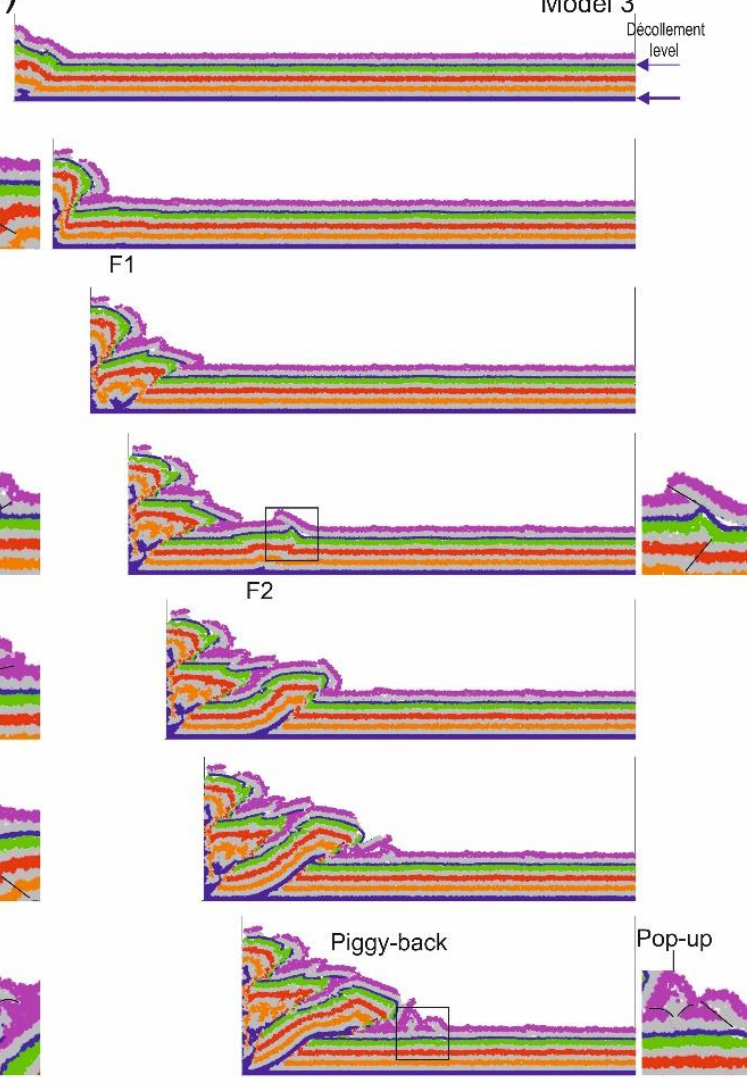

Fig. 2. Modelling results of model 1 (a), model 2 (b) and model 3 (c) in series 1. The enlarged boxes show features of structural decoupling above and below the upper décollement. 

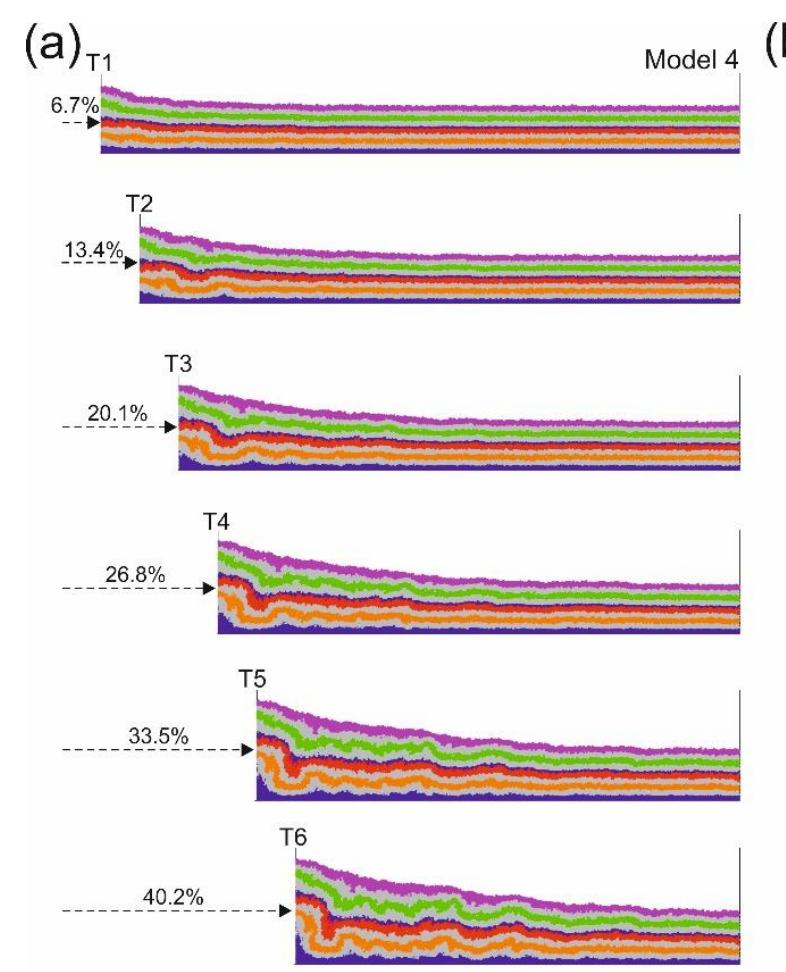

T7

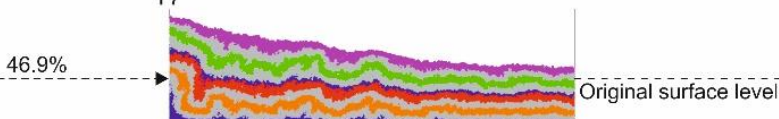

(b)
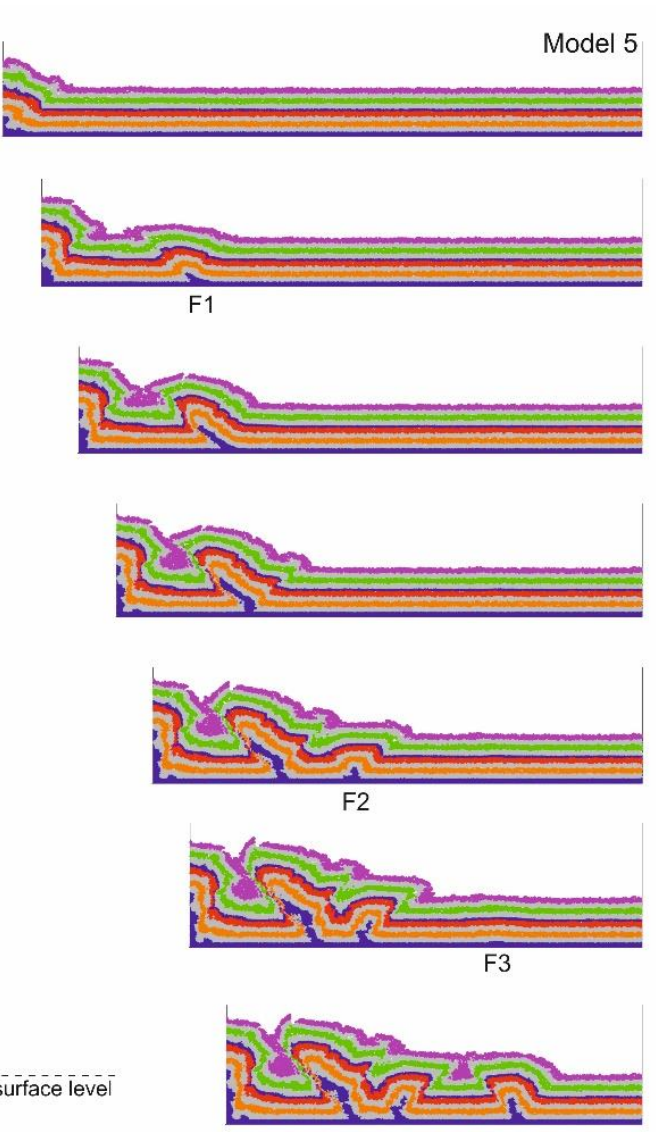

(c)
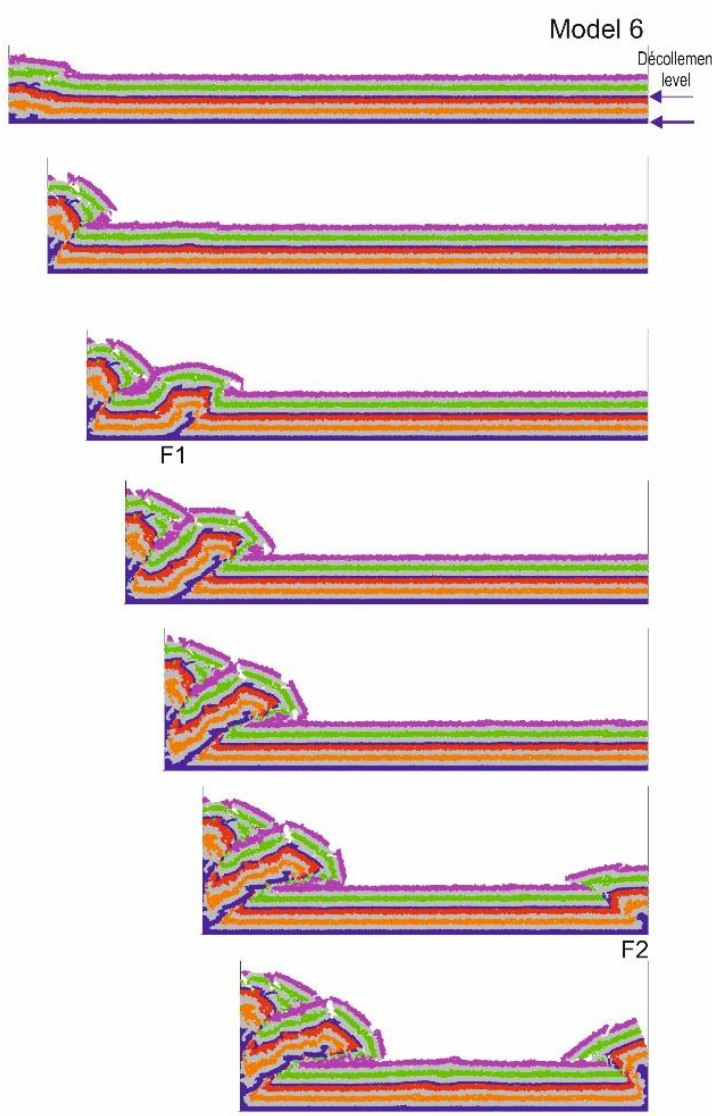

Fig. 3. Modelling results of model 4 (a), model 5 (b) and model 6 (c) in series 2. 
(a)
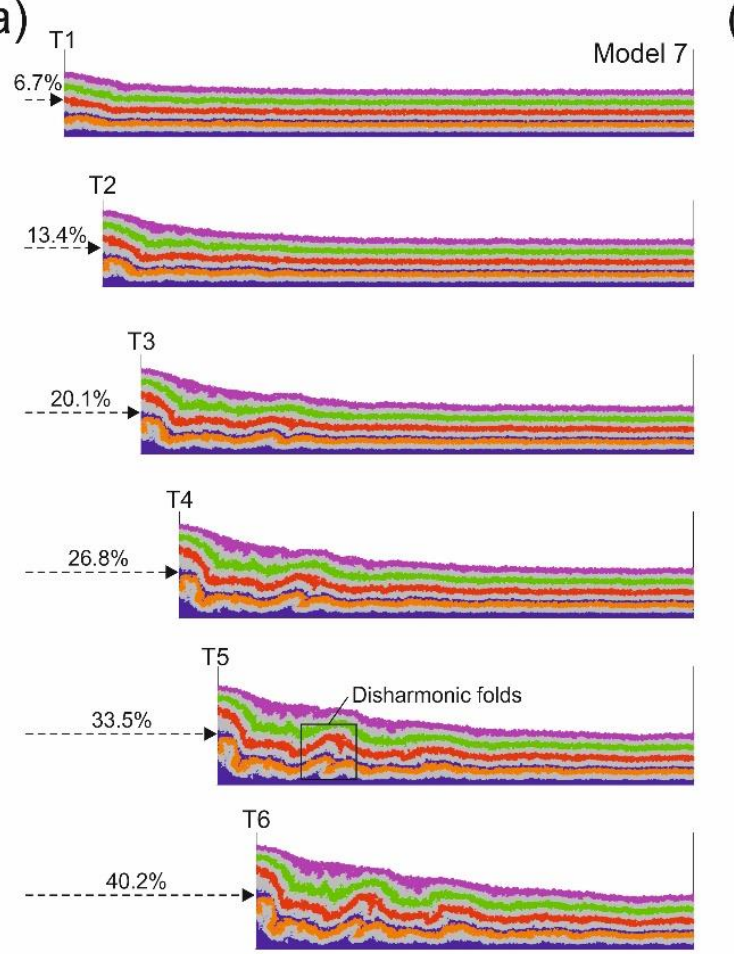

T7

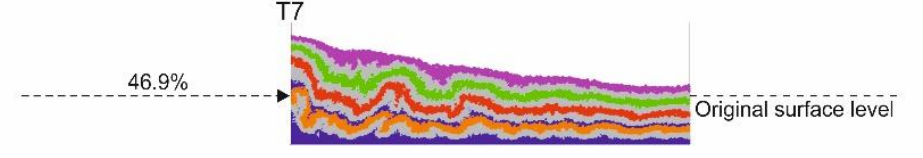

(b)
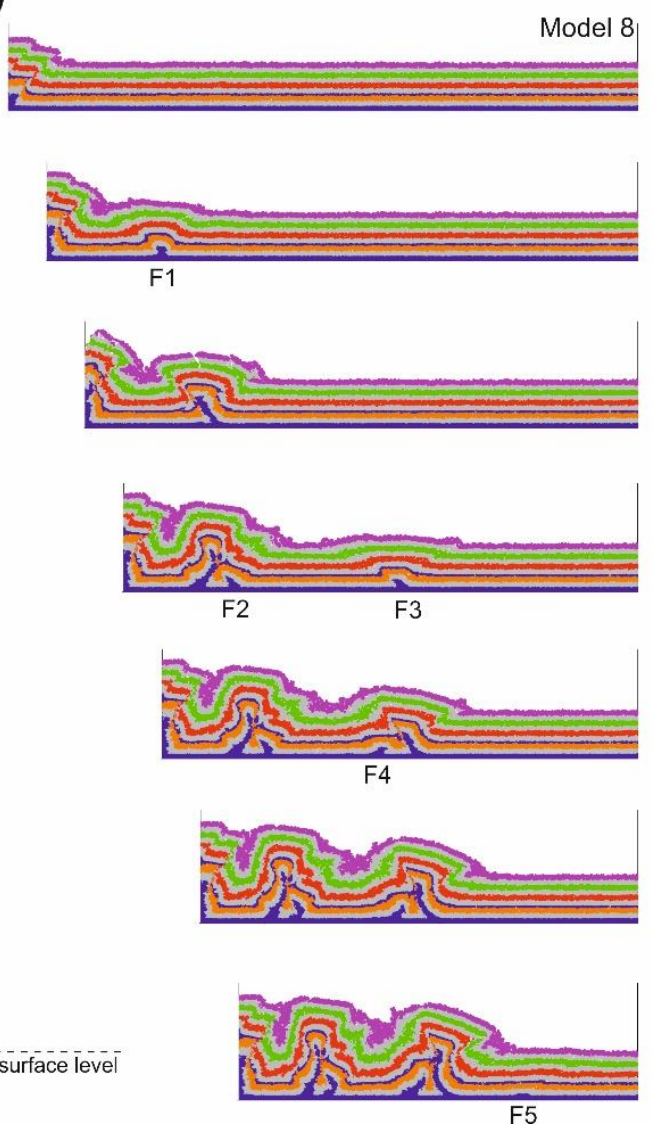

(c)
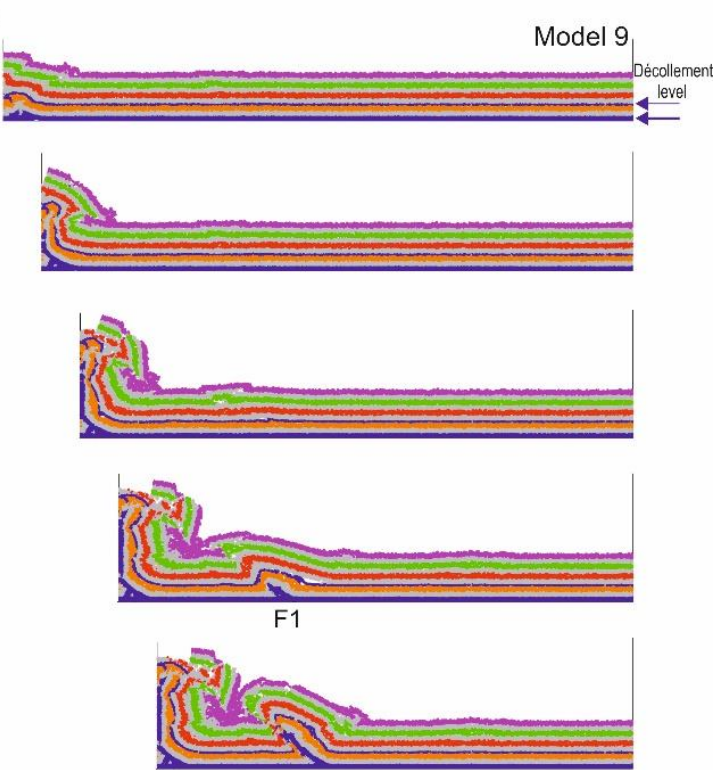

Tensile fracture
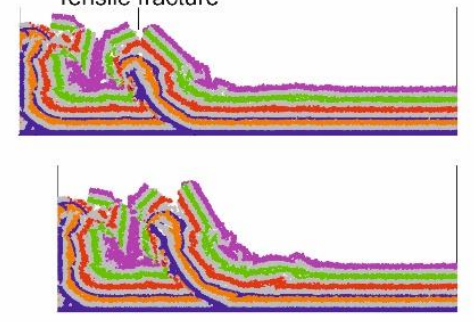

Fig. 4. Modelling results of model 7 (a), model 8 (b) and model 9 (c) in series 3. 
(a)
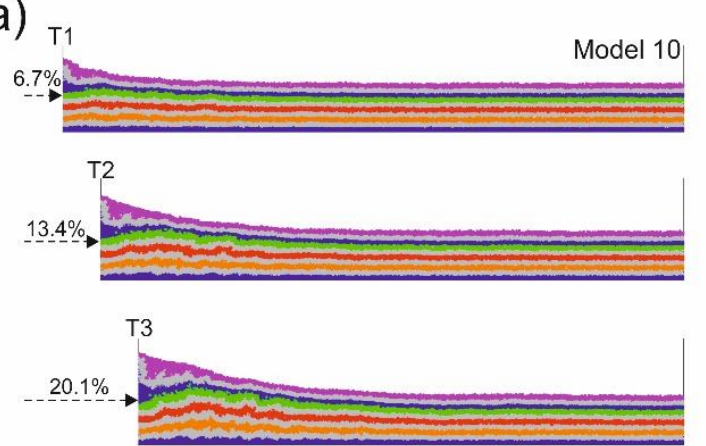

$\mathrm{T} 4$

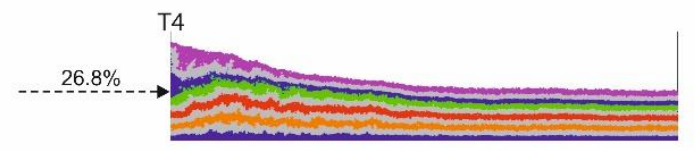

T5

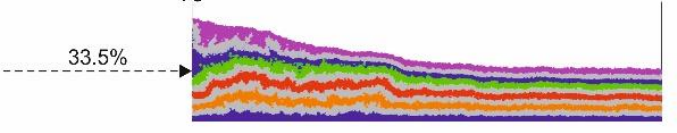

T6

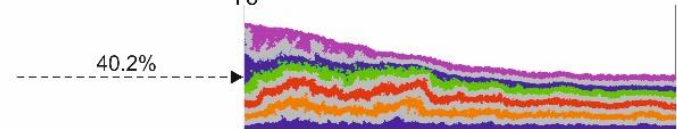

T7

$46.9 \%$

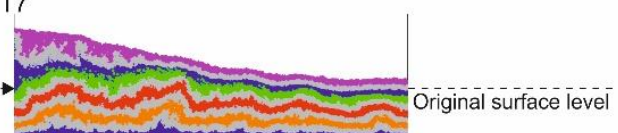

(b)
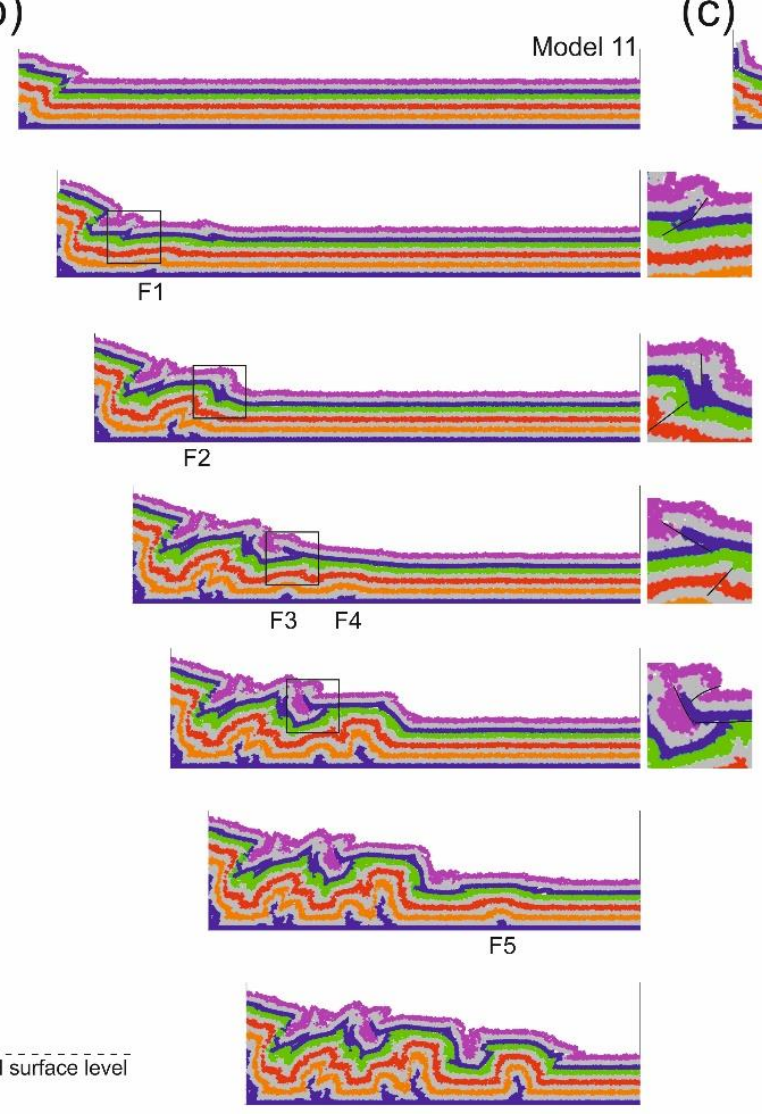

(c)
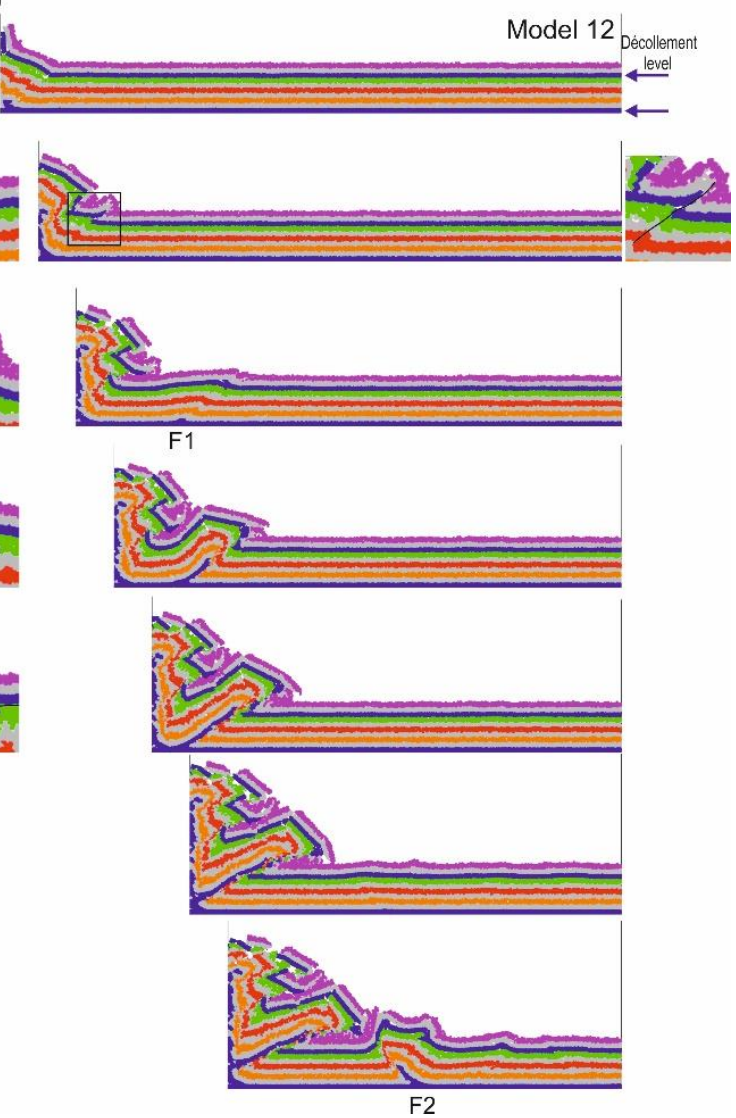

Fig. 5. Modelling results of model 10 (a), model 11 (b) and model 12 (c) in series 4 . The enlarged boxes show features of structural decoupling above and below the upper décollement. 
(a)
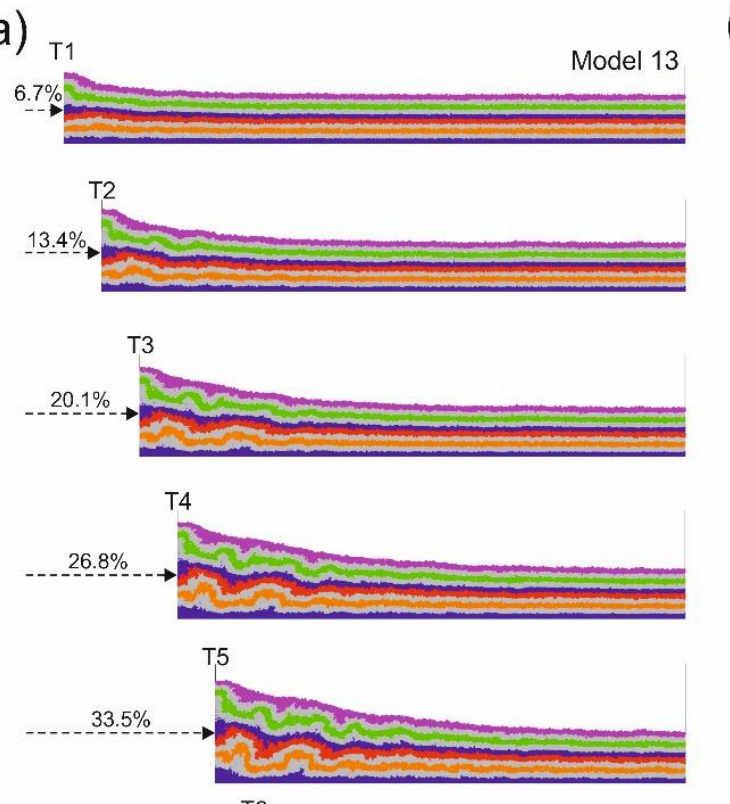

T6
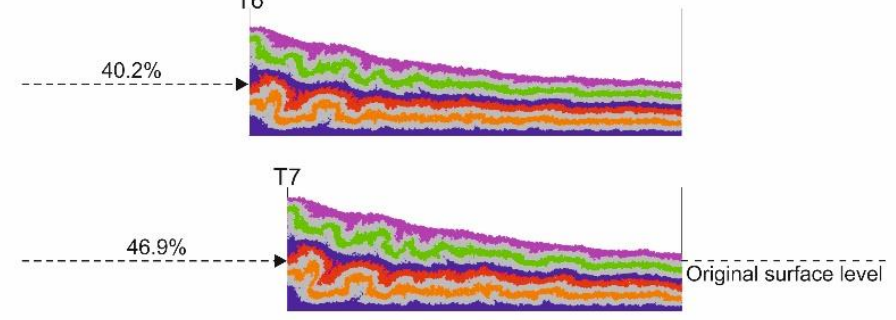

(b)
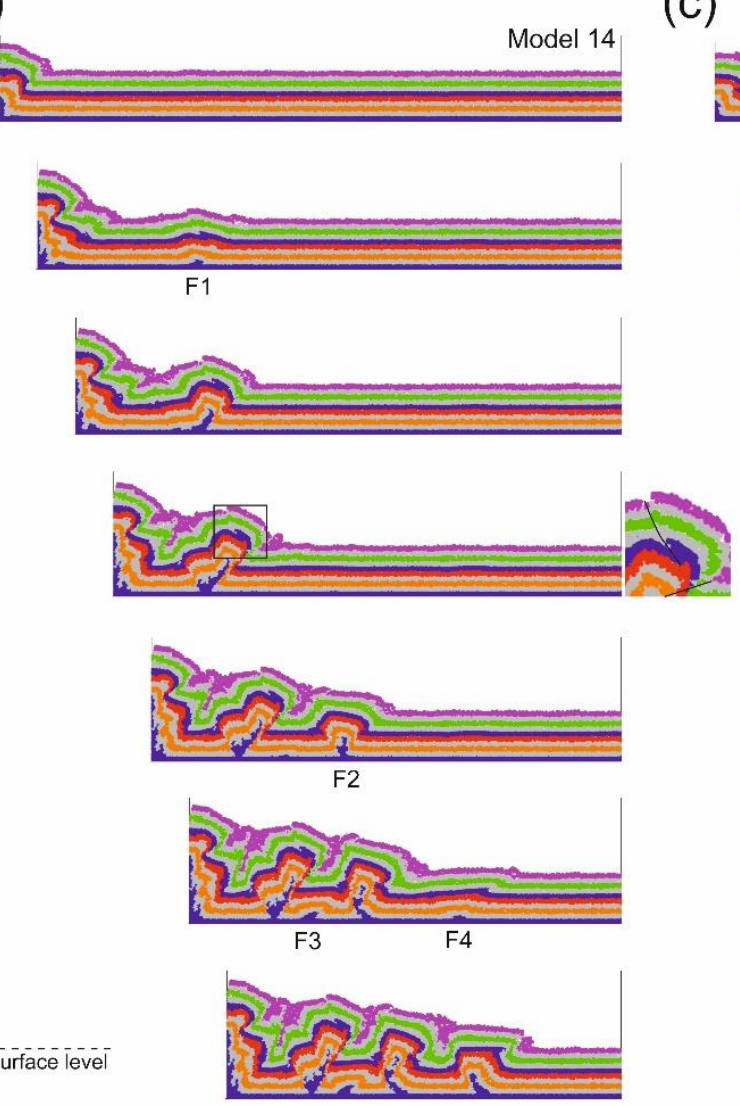

(c)
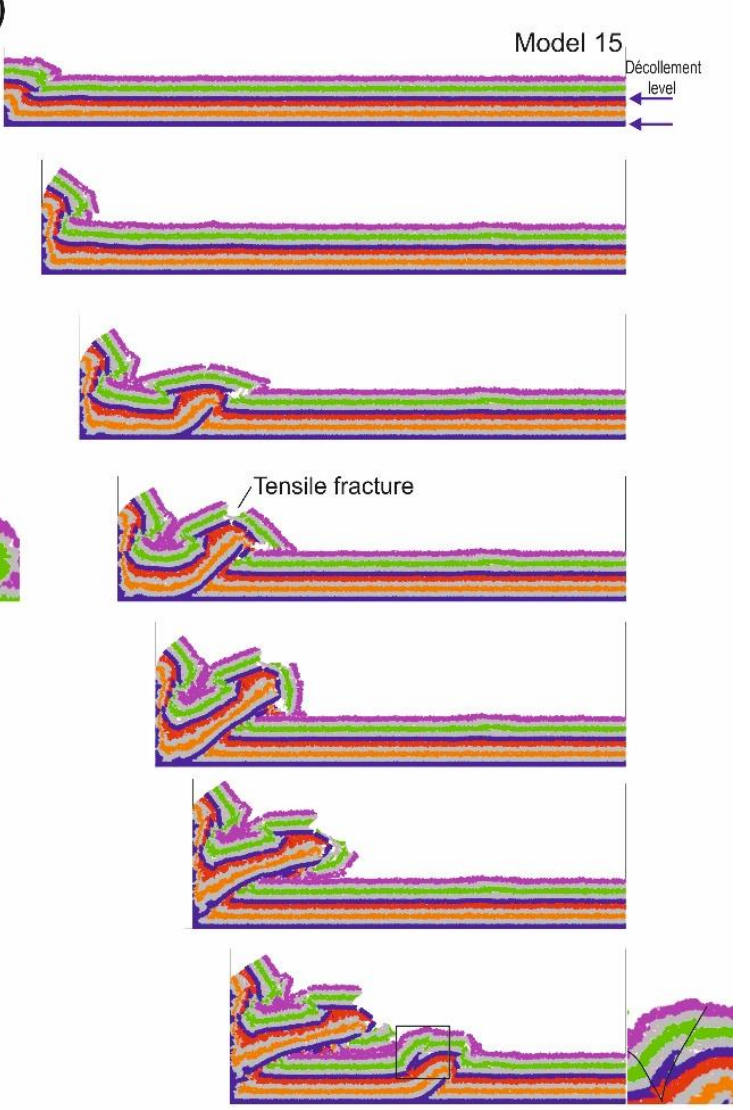

Fig. 6. Modelling results of model 13 (a), model 14 (b) and model 15 (c) in series 5. The enlarged boxes show features of structural decoupling above and below the upper décollement. 
(a)
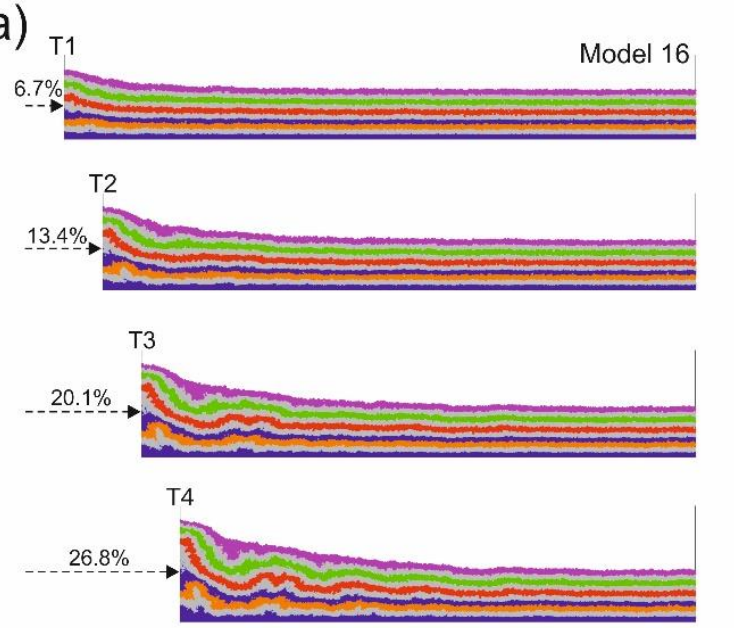

T5

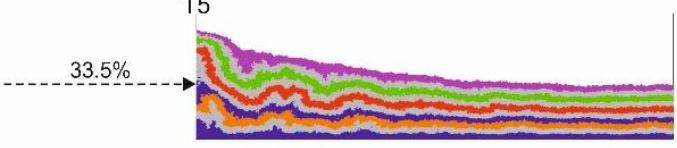

T6
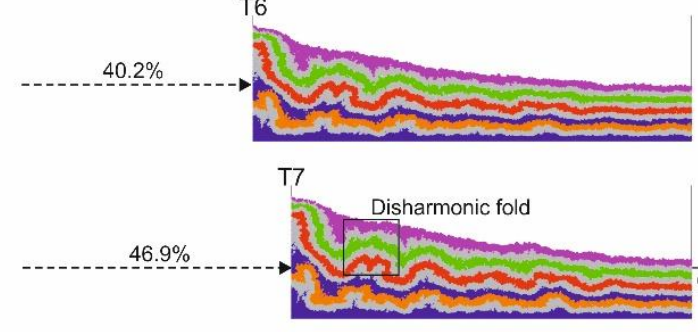

(b)
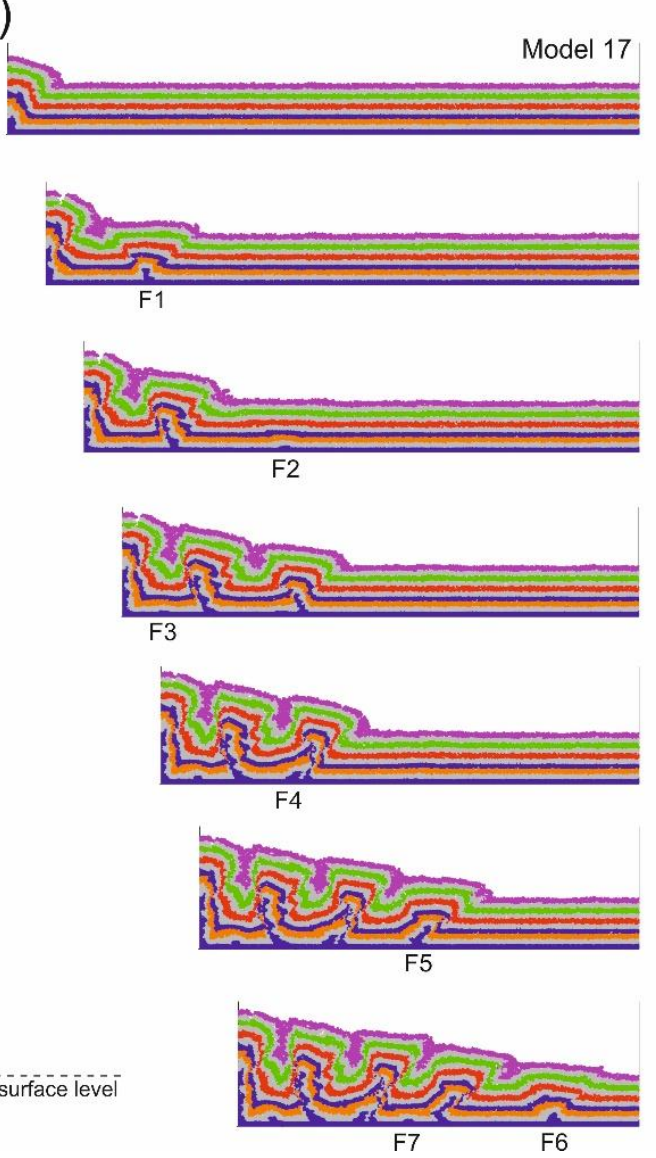

(c)
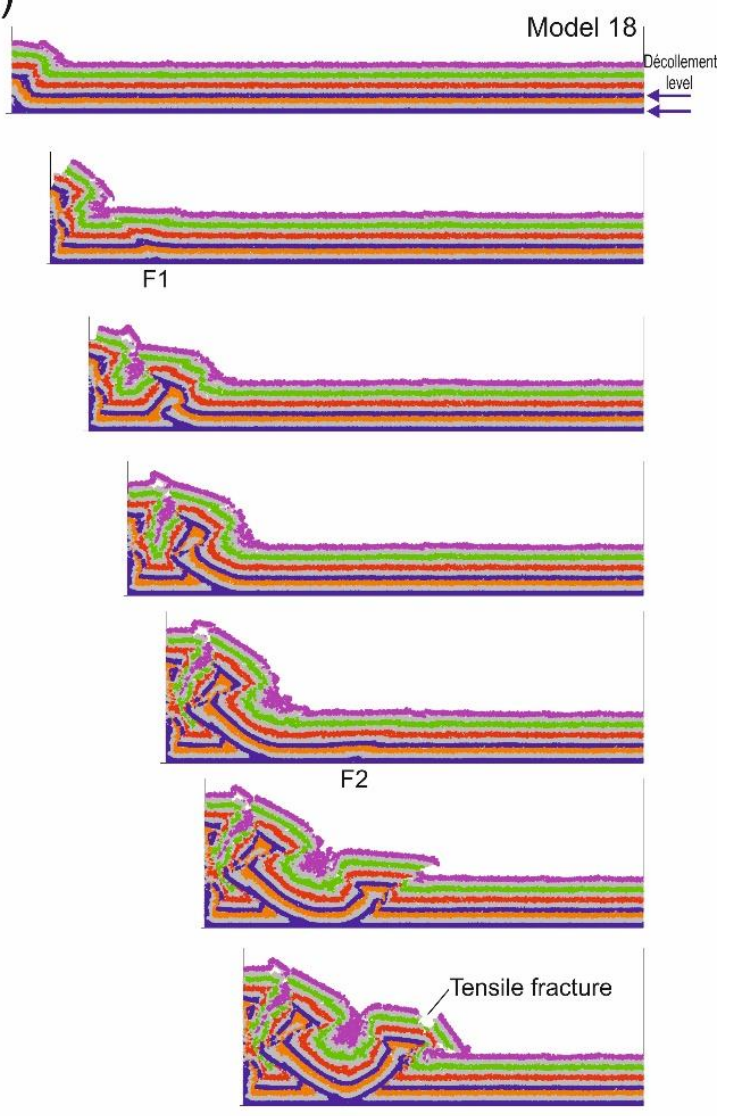

Fig. 7. Modelling results of model 16 (a), model 17 (b) and model 18 (c) in series 6. 


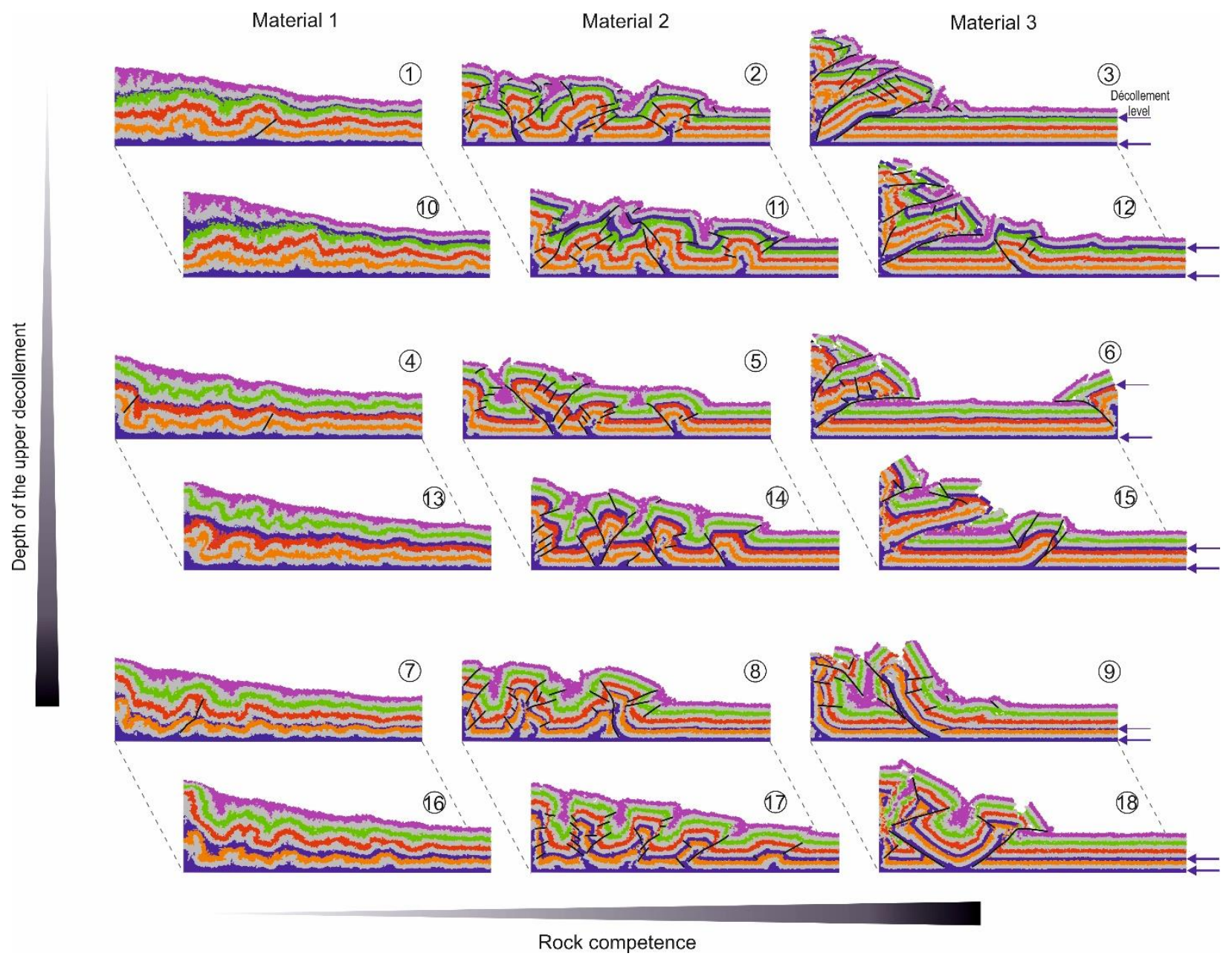

Fig. 8. Summary of modelling results of all models. Fault traces are highlighted by black solid lines. 
(a)

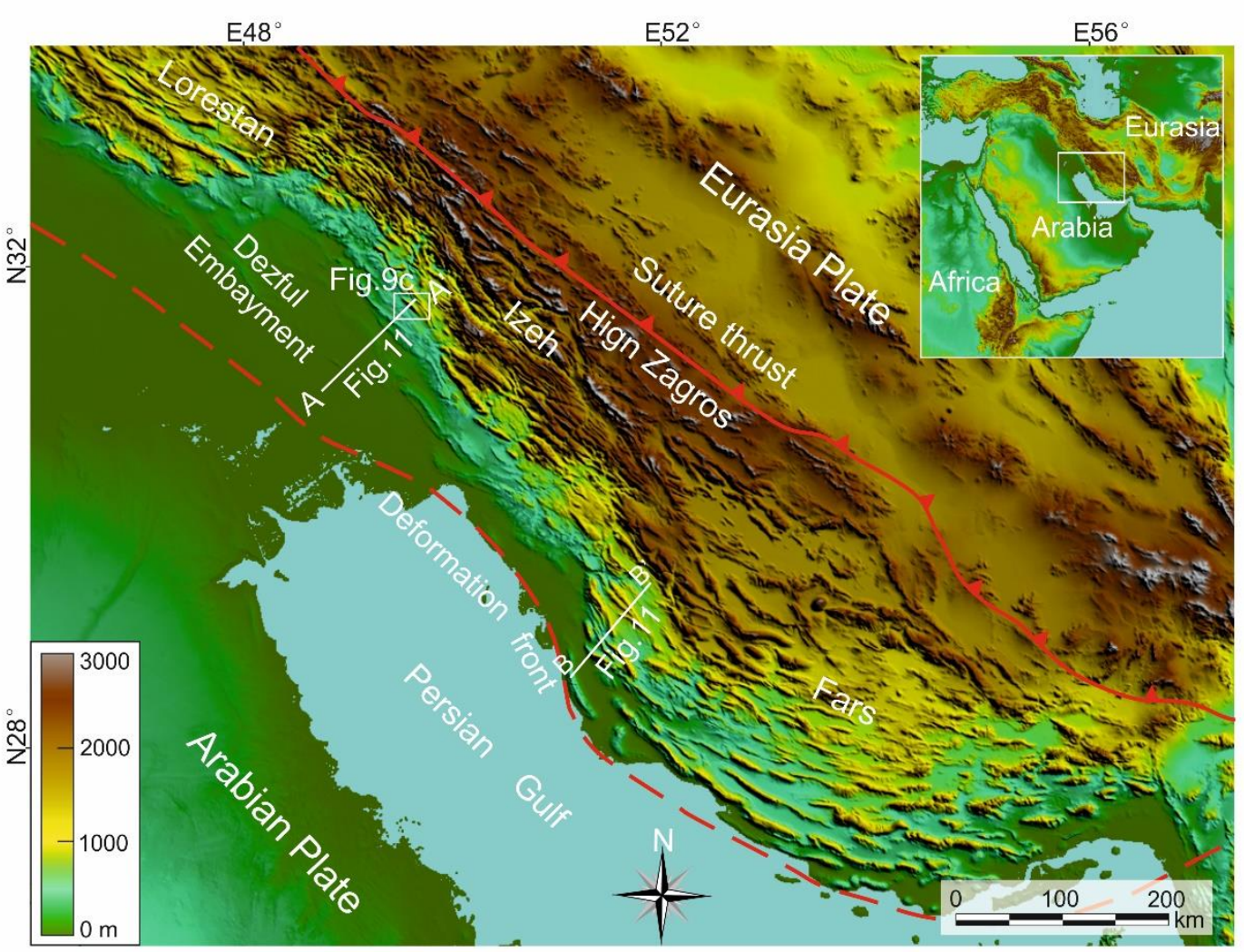

(b)

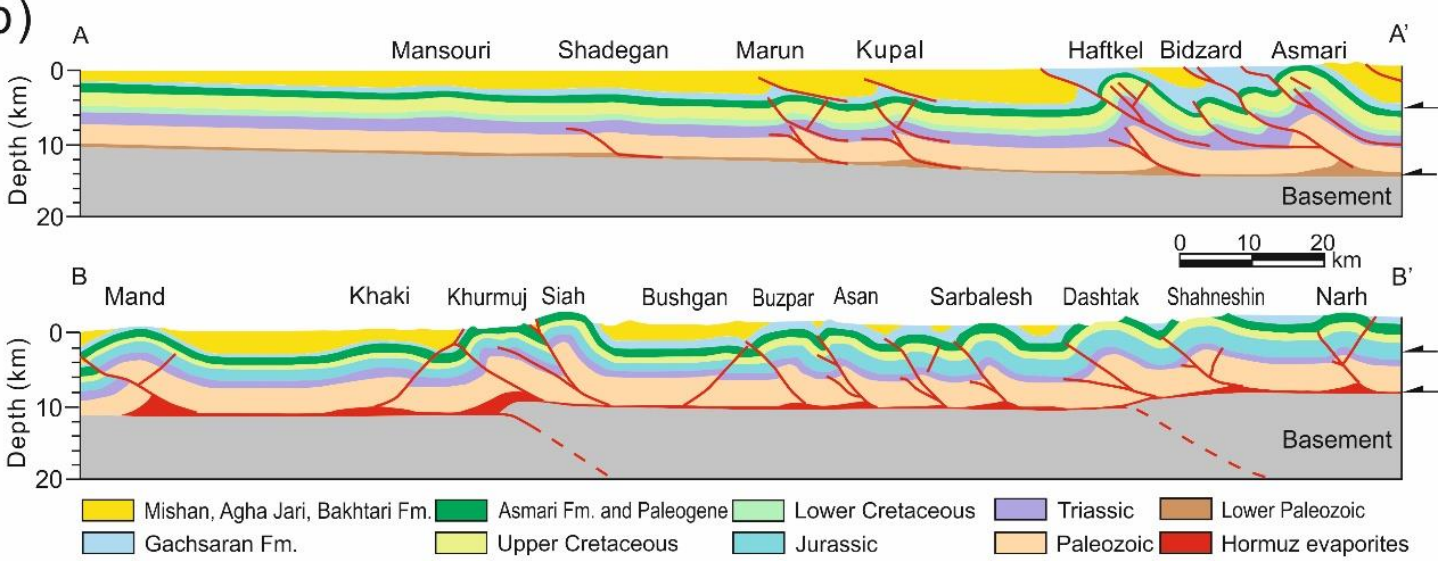

(c)

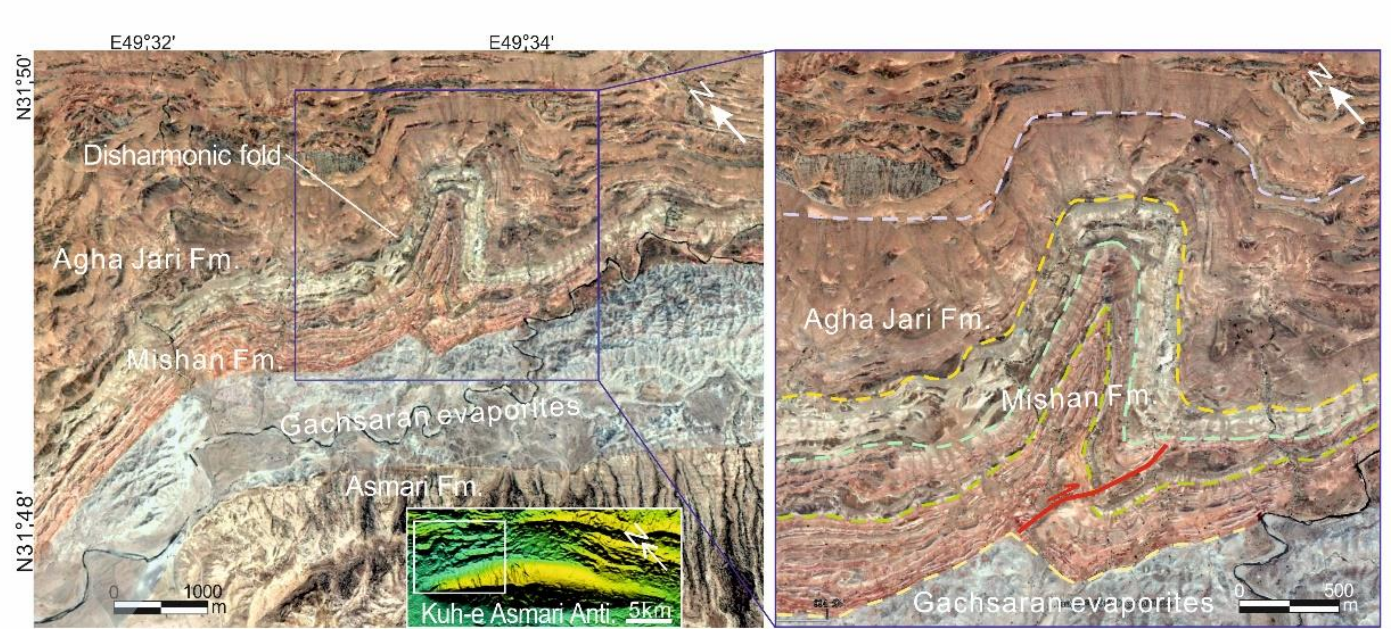


Fig. 9. (a) Elevation map showing the location and main structural elements of the Zagros Fold-and-Thrust Belt. (b) Cross sections of the Dezful Embayment and the Fars province. Modified from Sherkati et al (2006). See locations in Fig. 9a. (c) Google satellite image showing outcrop exposure of a minor disharmonic fold developed above the shallow Gachsaran evaporites in the Kuh-e Asmari Anticline. The image is located in the box area of the elevation map that shows the fold geometry. The enlarged box shows details of the disharmonic fold. The dashed lines highlight the bedding traces as markers for correlation. The reverse fault is marked by the red line. See location in Fig. 9a. 